\title{
PAREJAS DE HECHO Y PENSIÓN DE VIUDEDAD TRAS LAS ÚLTIMAS SENTENCIAS DEL TRIBUNAL CONSTITUCIONAL
}

\author{
Unmarried Couples and Widow's Pension after Recent Judgments \\ of the Constitutional Court
}

\author{
MAGDALENA UREÑA MARTÍNEZ \\ Profesora Titular de Derecho Civil \\ Universidad de Castilla-La Mancha
}

\author{
Recepción: 21/06/2015 \\ Aceptación después de revisión: 22/07/2015 \\ Publicación: 27/11/2015
}

I. EL ACCESO A LA PENSIÓN DE VIUDEDAD POR LAS PAREJAS DE HECHO: DUDAS SOBRE LA CONSTITUCIONALIDAD DE ALGUNOS DE LOS PRESUPUESTOS EXIGIDOS. II. UNA CUESTIÓN PREVIA: LA POSIBLE DISCRIMINACIÓN DE LAS PAREJAS DE HECHO HOMOSEXUALES EN EL ACCESO A LA PENSIÓN DE VIUDEDAD HASTA LA MODIFICACIÓN DEL CC POR LEY 13/2005. III. EL PRESUPUESTO DE «HABER TENIDO HIJOS EN COMÚN» EX DisPOSICIÓN ADICIONAL 3. a DE LA LEY 40/2007: SU INCONSTITUCIONALIDAD POR LA STC 41/2013 ANTE LA IMPOSIBILIDAD DE CUMPLIMIENTO POR PARTE DE ALGUNAS PAREJAS DE HECHO. IV. LA «CONSIDERACIÓN» Y «ACREDITACIÓN» DE LAS PAREJAS DE HECHO EX ARTÍ́CULO 174.3 LGSS: EL PROBLEMA DE LA REMISIÓN A LAS LEYES DE PAREJAS DE HECHO DE LAS COMUNIDADES AUTONÓMAS CON COMPETENCIA EN DERECHO CIVIL: 1. La declaración de inconstitucionalidad total y nulidad del párrafo $5 .{ }^{\circ}$ del artículo 174.3 LGSS por la STC 40/2014. 2. La declaración de inconstitucionalidad del párrafo 5. del artículo 174.3 LGSS y la competencia autonómica del artículo 149.1.8. ${ }^{a} C E$. V. LA INEXISTENCIA DE VÍNCULO MATRIMONIAL PREVIO EX ARTÍCULO 174.3 LGSS: SU CONSTITUCIONALIDAD POR LA STC 44/2014. VI. LA ACREDITACIÓN FORMAL DE LA PAREJA DE HECHO EX ARTÍCULO 174.3 LGSS: SU CONSTITUCIONALIDAD POR LAS SSTC 45/2014, 51/2014 y 60/2014. VII. A MODO DE CONCLUSIÓN. BIBLIOGRAFÍA.

\section{RESUMEN}

Pese a que el legislador de la Seguridad Social reconoce la pensión de viudedad a las parejas de hecho en la Ley 40/2007, de 4 de diciembre, de Medidas en Materia de la Seguridad Social, no las ha equiparado al matrimonio. El artículo 174.3.4. ${ }^{\circ}$ LGSS exige al conviviente supérstite que, además, de encontrarse en una situación de dependencia económica respecto del fallecido, cumpla unos presupuestos formales y de convivencia. La exigencia legal del cumplimiento 
cumulativo de dichos presupuestos ha generado en los tribunales de justicia importantes dudas jurídicas acerca de su constitucionalidad en relación con el principio de igualdad del artículo $14 \mathrm{CE}$. La finalidad del trabajo es analizar las sentencias del TC que han recaído sobre esta materia en los últimos años y conocer la situación actual de las parejas de hecho en torno a esta prestación de la Seguridad Social.

PALABRAS CLAVE: Parejas de hecho; matrimonio; pensión de viudedad; principio de igualdad y no discriminación y protección a la familia.

\section{ABSTRACT}

Although the legislator of the Social Security recognizes the widow's pension to common law partner in the Law 40/2007, the 4th of December, of Measures in Matter of the Social Security, has not compared to marriage. The art. 174.3.4. LGSS requires to the partner that, although he was in a situation of economic dependence related to the deceased, he must accomplish some formal and coexistence budgets. The legal requirement of cumulative compliance of these budgets has generated in the courts of law significant legal doubts about its constitutionality in relation to the principle of equality of art. $14 \mathrm{EC}$. The purpose of the work is to analyze the judgments of the TC that have relapsed on this subject in recent years and to know the current situation of common law partners around this benefit of the Social Security

KEY WORDS: Common law partners; marriage; survivor's pension; the principle of equality and non discrimination and protection of family.

\section{EL ACCESO A LA PENSIÓN DE VIUDEDAD POR LAS PAREJAS DE HECHO: DUDAS SOBRE LA CONSTITUCIONALIDAD DE ALGUNOS DE LOS PRESUPUESTOS EXIGIDOS}

Tradicionalmente la pensión de viudedad solo se concedía a las personas casadas ex artículo 174 LGSS. Las parejas de hecho no la tenían reconocida, lo que supuso que se plantearan continuas dudas ante los tribunales de justicia sobre si el no reconocimiento de la pensión de viudedad a las uniones de hecho podía vulnerar el principio de igualdad. El TC desde la conocida sentencia 184/1990, de 15 de noviembre, hasta la actualidad ha venido declarando que el distinto tratamiento dispensado por el legislador a los matrimonios y a las uniones de hecho, a efectos del derecho a la pensión de viudedad, no conculca el artículo $14 \mathrm{CE}$; la argumentación jurídica defendida en la sentencia citada del TC es que «el matrimonio y la convivencia extramatrimonial no son realidades equiva- 
lentes. El matrimonio es una institución social garantizada por la Constitución, y el derecho del hombre y de la mujer a contraerlo es un derecho constitucional (artículo 32.1). (...) Nada de ello ocurre con la unión de hecho more uxorio, que ni es una institución jurídicamente garantizada ni hay un derecho constitucional expreso a su establecimiento» (FJ $\left.3^{\circ}{ }^{0}\right)^{1}$. Con este planteamiento jurisprudencial puede afirmarse que no existe ningún obstáculo constitucional para que el legislador, dentro de su amplísima libertad de decisión, haya otorgado un trato distinto y más favorable al matrimonio que a las uniones convivenciales.

Pese a ser esta la posición jurisprudencial mayoritaria, no faltaron quienes defendían que las parejas de hecho debían tener una mayor protección social ${ }^{2}$. El transcurso del tiempo ha dado la razón a quienes entendían que la exigencia de estar casados - si se quería obtener la pensión de viudedad - era más bien fruto de una determinada moral y concepción religiosa de la sociedad de entonces ${ }^{3}$. Los importantes cambios sociales producidos en los últimos años, unido a los nuevos tipos de familia, exigían un cambio legislativo en la configuración del régimen jurídico de la pensión de viudedad ${ }^{4}$. Así, el legislador de la Seguridad Social a través de la Ley 40/2007, de 4 de diciembre, de Medidas en Materia de la Seguridad Social (en adelante LMMSS) decide otorgar

${ }^{1}$ Vid., entre otras, las sentencias de 29/1991, 31/1991, 35/1991 y 38/1991, todas ellas de 14 de febrero; 77/1991, de 11 de abril; 29/1992, de 9 de marzo; 69/1994, de 28 de febrero y 39/1998, de 17 de febrero que siguen la doctrina sentada por la citada STC 184/1990, de 15 de noviembre.

${ }^{2}$ Cfr., el voto particular formulado por don Luis López Guerra a la STC 184/1990, de 15 de noviembre, donde sostiene que el mayor reconocimiento social y protección constitucional del matrimonio no puede equivaler a «la posibilidad ilimitada de establecer tratamientos favorables para un conjunto de ciudadanos por el hecho de estar, o haber estado, casados frente a los que no ostentan tal condición. No basta cualquier diferencia de situación para justificar una diferencia de trato, pues es necesario, además, que el criterio diferenciador sea razonable y no arbitrario en relación con el resultado a conseguir. Aquí el elemento diferenciador es la existencia o no de vínculo matrimonial y el resultado es el disfrute de la pensión de viudedad, por lo que procede valorar si tal disfrute se justifica en función de la concurrencia del citado vínculo o debe atender a otras razones».

${ }^{3}$ En este sentido, Martínez Abascal, V. A., «Las parejas de hecho y la pensión de viudedad en la Ley 40/2007, de 4 de diciembre: ¿una equiparación inviable?», $A S$, n. ${ }^{\circ}$ 17, 2010 (BIB 2009, 1900), p. 7.

4 Vid., Panizo Robles, J. A., «La convivencia de hecho y su incidencia en las prestaciones de la Seguridad Social: una deuda de cobertura pendiente», Justicia Laboral, 2005, n. . 24, pp. 11 y ss.; GuTIÉRREZ-Solar CALVo, B., «Pensión de viudedad y convivencia extramatrimonial: un motivo más para una necesaria reforma del artículo 174 LGSS», Relaciones Laborales, n. ${ }^{\circ}$ 7, 2005, pp. 20 y ss. 
protección a las parejas de hecho ex artículo 174.3 LGSS ${ }^{5}$, concediéndoles la pensión de viudedad a partir del 1 de enero de $2008^{6}$ - pensión de viudedad de carácter general- . También para hechos acaecidos antes del 1 de enero de 2008, la Ley 40/2007 MMSS reconoce de manera excepcional una pensión de viudedad a las parejas de hecho, en virtud de lo establecido en su DA 3. .

A pesar de que el legislador de la Seguridad Social ha reconocido la pensión de viudedad a los convivientes more uxorio, no lo ha hecho en igualdad de condiciones con las uniones matrimoniales. Por un lado, el

${ }^{5}$ Sobre el alcance de la reforma introducida por la Ley 40/2007 puede consultarse: Alarcón CASTEllano, M. M. y Roldán Martínez, A., «Algunas reflexiones críticas sobre la pensión de viudedad de las parejas de hecho», Revista de Trabajo y Seguridad Social, n. . 319, 2009; ApILluelo MARTín, M., «La pensión de viudedad tras la nueva Ley 40/2007, de 4 de diciembre, de medidas en materia de Seguridad Social», Actualidad Laboral, n. ${ }^{\circ}$ 9, 2008; DESDENTADO DAROCA, E., La pensión de viudedad ante los nuevos retos del Derecho de Familia: Un estudio para una prestación en crisis, Bomarzo, Albacete, 2009 y La pensión de viudedad. Retos del Derecho de Familia y reflexiones sobre las últimas reformas, Bomarzo, Albacete, 2013; DíAz AzNARTE, M. T., «Las prestaciones por muerte y supervivencia en el ordenamiento jurídico español tras la Ley 40/2007, de 4 de diciembre, de medidas en materia de la Seguridad Social», en La reforma de la Seguridad Social. Estudio sistemático de la Ley 40/2007, de 4 de diciembre, de medidas en materia de Seguridad Social, dir., Monereo Pérez, J. L., La Ley, Madrid, 2008; Molins GARCíA-ATANCE, J., «La pensión de viudedad en la Ley 40/2007, de medidas en materia de Seguridad Social», Revista doctrinal Aranzadi Social, n. ${ }^{\circ}$ 6, 2008 (BIB 2008, 1180); Moreno VidA, M. a N., y Monereo Pérez, J. L., y Díaz AzNARTE, M. ${ }^{\text {a }}$ T., La pensión de viudedad. Una necesaria reforma ante los cambios en las estructuras familiares, Comares, Granada, 2013; PÉREZ AlONSO, M. A., Nueva pensión de viudedad y orfandad en el Régimen General de la Seguridad Social, Tirant lo Blanch, Valencia, 2008; RodRíGUEZ INIESTA, G., «La protección por muerte y supervivencia», en CAVAs Martínez, F. (Dir.), La reforma de la seguridad social de 2007, Ediciones Laborum, Murcia, 2007; SAMPEDRO CORRAL, M., «Modificaciones introducidas por la Ley 40/2007, de 4 de diciembre, en la prestación de muerte y supervivencia», Revista de Trabajo y Seguridad Social. CEF, n. ${ }^{\circ}$ 298, 2008; TosCANI GIMÉNEZ, D., «La reformulación de la pensión de viudedad en la Ley 40/2007: algunas reflexiones críticas», Revista de Trabajo y Seguridad Social. CEF, n. ${ }^{\circ}$ 302, 2008.

${ }^{6}$ Conviene recordar que el 13 de julio de 2006 se suscribe el Acuerdo sobre medidas en materia de Seguridad Social por el Gobierno, la Unión General de Trabajadores, la Confederación Sindical de Comisiones Obreras, la Confederación Española de Organizaciones Empresariales y la Confederación Española de la Pequeña y Mediana Empresa - que a su vez traía causa de la Declaración para el diálogo social, firmada por los mismos interlocutores el 8 de julio de 2004-, donde se incluían una serie de compromisos que afectaban a la pensión de viudedad. Entre otras medidas se acordó adecuar la acción protectora del sistema a las nuevas realidades sociales y así reconocer la pensión de viudedad a las parejas de hecho que acrediten «convivencia mutua, estable y notoria, durante un periodo amplio, a determinar en el desarrollo del Acuerdo». 
conviviente supérstite tendrá que probar que se encuentra en una situación de dependencia económica respecto del fallecido - pár. $1 .^{\circ}, 2{ }^{\circ}$ y $3 .^{\circ}$ del artículo 174.3 LGSS$^{7}$; aspecto que no se exige al cónyuge supérstite ya que recibirá la pensión de viudedad de manera automática con independencia de la situación económica en la que se encuentre, bastando con la prueba de la existencia de dicha relación matrimonial ex artículo 174.1 LGSS $^{8}$. Por otro, el conviviente supérstite deberá probar el cumplimiento de los presupuestos - formales y de convivencia - exigidos ${ }^{9}$.

Respecto de la pensión de viudedad de carácter general, el pár. $4 .{ }^{\circ}$ del artículo 174.3 LGSS condiciona la existencia de la pareja de hecho - a efectos de obtener la pensión de viudedad - , al cumplimiento de una serie de requisitos: a) un presupuesto previo de carácter subjetivo, relativo a que los sujetos no se hallen impedidos para contraer matrimonio y que no tengan un vínculo matrimonial subsistente con otra persona; b) una exigencia material, referida a la convivencia como pareja de hecho estable durante un periodo mínimo de cinco años inmediatamente anteriores a la fecha de fallecimiento del causante; y c) una exigencia formal, consistente en la verificación de que la pareja se ha constituido mediante inscripción en el registro de parejas de hecho o a través de documento público con dos años de antelación al fallecimiento del causante. Para la pensión de viudedad excepcional la DA 3. ${ }^{a}$ de la Ley 40/2007 también exige la concurrencia de los siguientes presupuestos: a) Que a la muerte del causante, reuniendo este los requisitos de alta y cotización del artículo 174.1 LGSS, no se hubiera podido causar derecho a pensión de viudedad; b) Que el beneficiario hubiera mantenido convivencia ininterrumpida, como pareja de hecho en los términos establecidos en el primer inciso, párrafo

${ }^{7}$ Con carácter general, el solicitante ha de acreditar que durante el año natural anterior al fallecimiento de su pareja sus ingresos no alcanzaron el 50 por 100 de la suma de los ingresos propios y los del causante en ese mismo lapso temporal. En el caso de que no existan hijos comunes con derecho a la pensión de orfandad, el límite se reduce al 25 por 100 de la suma de los ingresos propios y los del causante.

${ }^{8}$ Crítica con la exigencia de que las parejas de hecho deban probar la situación de insuficiencia económica, para percibir la pensión de viudedad, frente a las uniones matrimoniales que no deben probarla, porque se presume, se ha pronunciado BLASCO JOVER, C., «La igualdad ante la exigencia de pensión compensatoria para lucrar viudedad en parejas de hecho», en NREDT, 168, 2014, p. 210.

${ }^{9}$ El hecho de que el legislador eleve el nivel de exigencia, en cuanto a los requisitos exigidos a las parejas de hecho frente a las uniones matrimoniales, se debe, en opinión de BlÁzQuez Agudo, E. M. y y PRESA García-LóPEZ («Pensión de viudedad para las parejas de hecho: evolución normativa y jurisprudencial», NRDT, 168, 2014, p. 193), a «cierta desconfianza de legislador» hacia las uniones no matrimoniales. 
cuarto, del artículo 174.3 LGSS, con el causante, durante, al menos, los seis años anteriores a su fallecimiento; c) Que el causante y el beneficiario hubieran tenido hijos comunes; d) Que el beneficiario no tuviera reconocido derecho a pensión contributiva de la Seguridad Social; e) Que la correspondiente solicitud se presentara en el plazo improrrogable de los doce meses siguientes a la entrada en vigor de la Ley 40/2007, en cuyo caso la pensión reconocida tendría efectos económicos desde el día primero de 2007.

La exigencia del cumplimiento de todos los presupuestos aludidos - en función de que se solicite una pensión de viudedad general o excepcional - ha supuesto la denegación de la misma en muchas ocasiones a un grupo importante de parejas de hecho estables que no reunían alguno de ellos. Pero, además, alguno de los requisitos señalados ha generado en los tribunales de justicia importantes dudas jurídicas acerca de su constitucionalidad en relación con el principio de igualdad, acudiendo constantemente al TC para aclarar esta cuestión ${ }^{10}$. Precisamente, el trabajo tiene por objeto el análisis de las sentencias del TC que han recaído sobre esta materia en los últimos años, con la finalidad de conocer la situación actual de las parejas de hecho en torno a esta prestación de la Seguridad Social.

\section{UNA CUESTIÓN PREVIA: LA POSIBLE DISCRIMINACIÓN DE LAS PAREJAS DE HECHO HOMOSEXUALES EN EL ACCESO A LA PENSIÓN DE VIUDEDAD HASTA LA MODIFICACIÓN DEL CC POR LEY 13/2005}

Con carácter previo al análisis de las dudas constitucionales suscitadas respecto de los presupuestos exigidos a las parejas de hecho a efectos de obtener la pensión de viudedad, conviene examinar otra cuestión, planteada ante el TC y relacionada con la materia que se analiza, que no ha estado exenta de polémica jurisprudencial. Me refiero a la posible discriminación de las uniones de hecho homosexuales en el acceso a la pensión de viudedad hasta la modificación del artículo 44

${ }^{10}$ Un sector de la doctrina social consideraba que los diferentes requisitos exigidos a las personas casadas y a las parejas de hecho en el acceso a la pensión de viudedad suponían un trato desigual no justificado, que constituía una vulneración del artículo 14 CE. Cfr., Lamarca, A., y Alascio, L., «Parejas de hecho y pensión de viudedad», en Indret, 2007, n. ${ }^{\circ}$ 4, p. 26; PoQuET CATALÁ, R., «El acceso de las parejas de hecho a la pensión de viudedad: ¿una realidad?, Temas Laborales, n. ${ }^{\circ}$ 119, 2013, p. 184. 
CC por la Ley 13/2015, de 1 de julio, que permite el matrimonio entre personas del mismo sexo ${ }^{11}$.

Conviene recordar que antes de la citada reforma del CC, únicamente las personas casadas accedían a la pensión de viudedad ex artículo 174.1 LGS, en la redacción dada por el artículo 32.1 de la Ley $50 / 1998$, de 30 de diciembre, de medidas fiscales, administrativas y del orden social: «Tendrá derecho a la pensión de viudedad, con carácter vitalicio (...), el cónyuge superviviente (...)». De este modo, al no existir posibilidad legal alguna de contraer matrimonio por parte de las personas del mismo sexo, estas nunca se encontrarían en la situación legal - matrimonio-, exigida por el citado precepto, con la consiguiente imposibilidad de conseguir la pensión de viudedad. Ante la duda constitucional generada, el Pleno del TC ha planteado una cuestión interna de inconstitucionalidad en relación a dicho precepto, por posible desigualdad en el trato de las parejas homosexuales respecto de las heterosexuales (art. 14.1 CE) - que sí podían contraer matrimonio - y por discriminación por razón de la orientación sexual (art. 14.2 CE).

La STC 92/2014, de 10 de junio, desestima la cuestión de inconstitucionalidad suscitada, pronunciándose a favor de la constitucionalidad del citado artículo 174.1. ${ }^{\circ}$ LGSS, al entender que la exigencia del vínculo matrimonial como presupuesto de acceso a la pensión de viudedad no vulnera el principio de igualdad. El TC, en su FD $6 .^{\circ}$, siguiendo la

${ }^{11}$ Un problema, que suscitó la Ley 13/2005 - que permite el matrimonio entre personas homosexuales - , era que no contaba con norma transitoria alguna que permitiera la aplicación de lo en ella dispuesto a situaciones anteriores a su entrada en vigor. Ante esta situación, algunos pretendieron la aplicación por analogía de lo previsto en la Ley 30/1981, de 1 de julio, que modificó la regulación del matrimonio en el CC y determinó el procedimiento a seguir en las causas de nulidad, separación y divorcio, cuya DA 10. ${ }^{\text {a }}$ permitía el acceso a la pensión de viudedad a quienes no hubieran podido contraer matrimonio, por impedírselo la legislación vigente hasta la fecha, pero hubieran vivido como tal, siempre que el fallecimiento de uno de ellos se hubiese producido con anterioridad a la vigencia de la citada Ley. Sobre esta cuestión el TS en la sentencia de 29 de abril de 2009 (RJ 2009, 4165) se pronuncia contrario a la aplicación de la DA 10 . $^{a}$ de la Ley 30/1981 al supérstite de pareja homosexual fallecido con anterioridad a la entrada en vigor de la Ley 13/2005 y, por ende, contrario al abono de la pensión de viudedad. En opinión del TS, la razón de ser de la DA 10. a de la Ley 30/1981 era la imposibilidad legal de disolver el primer vínculo para contraer un nuevo matrimonio, mientras que la razón de ser de la Ley 13/2005, no es la eliminación de una discriminación preexistente, sino la instauración de algo nuevo - el matrimonio entre personas homosexuales - , eliminando una concepción anticuada acerca de la naturaleza de las relaciones de convivencia entre parejas del mismo sexo. 
doctrina sentada en resoluciones anteriores, señala que la exigencia del matrimonio no pugna con el artículo $14 \mathrm{CE}$ por la razón esencial de que la unión entre personas del mismo sexo biológico no es una institución jurídicamente regulada, ni existe un derecho constitucional a su establecimiento; todo lo contrario al matrimonio entre hombre y mujer que es un derecho constitucional (art. 32.2) que genera ope legis una pluralidad de derechos y deberes (STC 184/1990 y ATC 222/1994). El hecho de que se traten de dos realidades no equivalentes justifica que los poderes públicos puedan otorgar un trato privilegiado, como la pensión de viudedad, a la unidad familiar constituida por hombre y mujer frente a una unión homosexual (ATC 222/1994), sin que suponga una conculcación del artículo $14 \mathrm{CE}$.

A mayor abundamiento, el Alto Tribunal incide en la amplia libertad del legislador para configurar el régimen de las prestaciones económicas de la Seguridad Social y, por tanto, para decidir acerca de las situaciones que deban o no considerarse merecedoras de protección social. Por ese motivo, y dentro de ese amplio margen de apreciación, el legislador decidió restringir en la LGSS de 1994 la pensión de viudedad a los supuestos en los que existía un vínculo matrimonial entre causante y beneficiario. Las uniones de hecho heterosexuales quedaban excluidas porque, pudiendo acceder al matrimonio, decidieron libremente no hacerlo y, por tanto, no cumplir con los requisitos legales (cfr., STC 184/1990, FJ 1). Las uniones homosexuales también quedaban fuera de la esfera de protección - si bien por razón distinta - porque la configuración tradicional del matrimonio se basaba en la idea de que las uniones homosexuales tenían una funcionalidad distinta a las heterosexuales dentro de la sociedad - afortunadamente cambia esta concepción a partir de la citada reforma 13/2005 CC, que permite el matrimonio entre personas homosexuales-. Finalmente, entiende el TC que no puede actuar como «legislador positivo retrospectivo y comprometiendo desembolsos económicos del erario público», de modo que remite al legislador ordinario la decisión de extender la protección de la pensión de viudedad a las uniones de hecho estables heterosexuales y homosexuales.

Esta sentencia cuenta con un voto particular, formulado por don Luis Ignacio Ortega Álvarez - al que se adhieren doña Adela Asúa Batarrita, don Fernando Valdés Dal-Ré y don Juan Antonio Xiol Ríos-, discrepante con la constitucionalidad del pár. 1. ${ }^{\circ}$ del artículo 174 LGSS, que permitía la diferencia de trato aludida en el acceso a la pensión de viudedad. Desde su punto de vista, no se trataba de un problema de diferencia de trato normativo entre matrimonio y parejas 
de hecho, sino de que las parejas de hecho homosexuales no tenían libertad para decidir si querían o no contraer matrimonio hasta la reforma del artículo 44.2 CC por la Ley 13/2005, de 1 de julio. Y, precisamente, esa falta de libertad de elección era la que generaba la consiguiente imposibilidad de cumplir con el requisito determinante del nacimiento de la prestación de viudedad - estar casados - por parte de dichas uniones homosexuales. A mayor abundamiento, si la libertad de elección es la condición inexcusable que legitima el tratamiento diferenciado en cuanto al acceso a la pensión de viudedad, dicho fundamento - legitimador del diferente trato - no concurre cuando se trata de parejas de hecho homosexuales, en la medida en que en la fecha del fallecimiento de uno de sus miembros no tenían reconocido el derecho a contraer matrimonio y, por tanto, el acceso a la pensión de viudedad $^{12}$. Por ese motivo, dicho Voto particular considera que debería haberse declarado la inconstitucionalidad de la diferencia de trato en el acceso a la pensión de viudedad, al estar legalmente impedidas las parejas de hecho homosexuales, para contraer matrimonio y acceder a la pensión de viudedad.

Posteriores sentencias del TC han resuelto recursos de amparo ${ }^{13}$, donde se ha planteado nuevamente la posible vulneración del principio de igualdad, tras la denegación de la pensión de viudedad a la pareja supérstite de homosexual por la inexistencia de vínculo matrimonial, al no existir en aquel momento posibilidad legal alguna de contraer matrimonio entre personas del mismo sexo. El TC se muestra partidario de la denegación del amparo solicitado, al entender que no se vulnera el principio de igualdad, en las sentencias 93/2014, de 12 de junio, 98/2014, de 23 de junio, 115/2014 y 116/2014, de 8 de julio, 124/2014, de 21 de julio y 157/2014, de 6 de octubre.

${ }^{12}$ El voto particular formulado a la STC 92/2014 no tiene desperdicio alguno. Vid., las críticas, formuladas en el punto 4, a los argumentos barajados por el TC a favor de la constitucionalidad de la diferencia de trato en el acceso a la pensión de viudedad.

${ }^{13}$ En un supuesto de hecho similar y bajo la aplicación del antiguo artículo 160 LGSS - que solo permitía el acceso a la pensión de viudedad a las personas casadas -, se interpone un recurso de amparo ante la denegación de la pensión de viudedad, solicitada por una persona homosexual que había convivido durante cuarenta años con el fallecido. El Auto del TC 222/1994, de 11 de julio, inadmite dicho recurso, al entender que «se debe admitir la plena constitucionalidad del principio heterosexual como calificador del vínculo matrimonial», de modo «que los poderes públicos puedan otorgar un trato de privilegio a la unión familiar constituida por hombre y mujer frente a la unión homosexual». 


\section{EL PRESUPUESTO DE «HABER TENIDO HIJOS EN COMÚN» $E X$ DA 3. a DE LA LEY 40/2007: SU INCONSTITUCIONALIDAD POR LA STC 41/2013 ANTE LA IMPOSIBILIDAD DE CUMPLIMIENTO POR PARTE DE ALGUNAS PAREJAS DE HECHO}

La Disposición Adicional 3. ${ }^{a}$ LMMSS estableció una regla especial de Derecho transitorio, pensada para atender situaciones de necesidad acaecidas con anterioridad a la entrada en vigor de dicha reforma legal, donde permitía al conviviente supérstite el acceso a la pensión de viudedad - con carácter excepcional-, siempre que cumpliera de manera cumulativa los presupuestos aludidos en el epígrafe 1 . De los requisitos exigidos, el relativo a «haber tenido hijos en común» resultaba de imposible cumplimiento para algunas parejas de hecho heterosexuales - que no habían tenido hijos por causa de infertilidad- y sobre todo para las parejas homosexuales a las que les resultaba extraordinariamente complicada la adopción.

Respecto de la adopción de menores, hay que tener presente que a

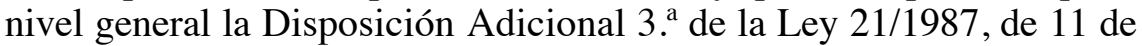
noviembre, solo permitía la adopción conjunta por parte de las parejas de hecho heterosexuales, al ser equiparadas en este punto al matrimonio, pero no extendía la equiparación a las parejas homosexuales. Es cierto que algunas Comunidades Autónomas con competencia en materia de Derecho Civil habían permitido a las parejas de hecho homosexuales la adopción conjunta y la adopción individual del hijo del conviviente, $v$. $g r$., el artículo 8 de la Ley Foral de Navarra 6/2000, de 3 de julio, de igualdad jurídica de las parejas estables ${ }^{14}$ y el artículo 8 de la Ley del País Vasco 2/2003, de 7 de mayo, reguladora de las parejas de hecho ${ }^{15}$; sin embargo, en la práctica resultó extraordinariamente difícil constituir una adopción en estos términos. Conviene recordar que el artículo 8 de la Ley Foral de Navarra 6/2000, pese a que fue recurrido por inconstitucional, siguió vigente, al carecer de efectos suspensivos en virtud de lo dispuesto en el artículo 30 LOTC; lo que permitió en algún caso la adopción por parte de una pareja de hecho homosexual (cfr., el Auto de 22 de

${ }^{14} \mathrm{El}$ artículo 8 establece que «los miembros de la pareja estable podrán adoptar de forma conjunta con iguales derechos y deberes que las parejas unidas por matrimonio».

${ }^{15} \mathrm{El}$ artículo 8 dispone que «los miembros de parejas formadas por dos personas del mismo sexo podrán adoptar de forma conjunta, con iguales derechos y deberes que las parejas formadas por dos personas de distinto sexo y las parejas unidas por matrimonio». En su apartado segundo añade que «la hija o hijo adoptivo o biológico de una de las partes de la pareja tendrá derecho a ser adoptado por la otra parte». 
enero de 2003 dictado por el Juzgado de Primera Instancia n. ${ }^{\circ} 3$ de Pamplona que acordó la adopción a favor de la compañera sentimental de la madre biológica de dos niñas gemelas nacidas por inseminación artificial). Por su parte, el artículo 8 de la Ley vasca 2/2003 quedó suspendido, tras el recurso de inconstitucionalidad promovido por el presidente del Gobierno, que invocó la aplicación del artículo 161.2 CE ${ }^{16}$.

A partir de la reforma del CC por la Ley 13/2005, de 1 de julio, que permite el matrimonio entre personas del mismo sexo, es posible con carácter general la adopción de menores por matrimonios homosexuales y, por tanto, la extensión de la DA 3. ${ }^{a}$ de la Ley 21/1987 -que permitía la adopción a las parejas de hecho heterosexuales - a las parejas de hecho homosexuales ${ }^{17}$. Admitida la posibilidad de que las uniones homosexuales pudieran tener hijos en común a través del trámite de la adopción, la dificultad surgía porque el plazo de tiempo existente para su formalización era bastante escaso - desde julio de 2005 hasta diciembre de 2007 - , por lo que la posibilidad de concluir los trámites de la adopción con éxito fueron prácticamente imposibles y, por ende, la obtención de la pensión de viudedad de carácter excepcional en los términos mencionados en la DA 3. ${ }^{\text {a }}$ LMMSS.

En suma, antes del 1 de enero de 2008 las parejas heterosexuales eran mayoritariamente las que podían «haber tenido hijos en común» - por naturaleza o por adopción a partir de la DA 3. ${ }^{a}$ Ley 21/1987-, accediendo a la pensión de viudedad. Por su parte, para las parejas homosexuales había resultado casi imposible haber tenido descendencia en común, ya sea porque hasta 2005 no se permitía la adopción salvo en alguna $\mathrm{CA}-v . g r$., Navarra aunque limitado a las parejas homosexuales formadas por mujeres-, ya sea por la dificultad de terminar los trámites de la adopción antes del 1 de enero de 2008. El presupuesto exigido por la DA 3. ${ }^{a}$ LMMSS de «haber tenido hijos en común» resultaba de imposible cumplimiento para aquellas parejas heterosexuales que no habían podido tener hijos por causa de infertilidad, pero resultaba prácticamente imposible para la generalidad de las parejas de hecho homosexuales, sobre todo, para las formadas por hombres y de difícil cumplimiento para aquellas cuyos miembros eran mujeres. Esto supuso que se planteara desde el inicio una duda sobre la constitucionalidad de dicho requisito, para conseguir la pensión de viudedad.

${ }^{16}$ El posterior desistimiento del recurso dejó sin efecto la suspensión $c f r$., ATC 544/2004, de 14 de diciembre.

17 Vid., la STC 198/2012, de 6 de noviembre, que admite la constitucionalidad de los matrimonios homosexuales y, por ende, su posibilidad de adoptar. 
Al Juzgado de lo Social n. ${ }^{\circ} 33$ de Barcelona se le había formulado una demanda contra una resolución administrativa en la que el INSS había denegado la pensión de viudedad a un varón - supérstite de una pareja de hecho homosexual masculina-, que había convivido de forma estable desde 1982 hasta 2004, basándose en que no se cumplía el requisito de «haber tenido hijos en común» con el causante, exigido en la DA 3. . LMMSS. Dicho Juzgado mediante el Auto de 11 de noviembre de 2008 acordó plantear una cuestión de inconstitucionalidad acerca de la aplicación de dicho presupuesto, al entender que su exigencia podía comportar la vulneración del artículo $14 \mathrm{CE}$ : «toda vez que el requisito de haber tenido hijos en común, cuando el fallecimiento del causante hubiera tenido lugar antes del 1 de enero de 2008, resulta de imposible cumplimiento para las parejas de hecho del mismo sexo si se trata de hijos biológicos y de muy difícil cumplimiento en la práctica si se trata de hijos adoptivos, pues el derecho de las parejas de hecho - heterosexuales u homosexuales - a adoptar solo se ha reconocido en Cataluña a partir de la Ley del Parlamento catalán 3/2005, de 8 de abril, de forma que era imposible la adopción si el fallecimiento acaeció con anterioridad, como sucede en el caso enjuiciado».

Concluye el Juzgado de lo Social citado con la afirmación de que la exigencia del referido requisito, aparentemente neutral, podría suponer un trato discriminatorio para las parejas de hecho del mismo sexo, por su efecto excluyente de la pensión de viudedad. Por el contrario, el Fiscal General y el Abogado del Estado coinciden en sus escritos de alegaciones en que la mencionada DA 3. ${ }^{\mathrm{a}}$ contiene una norma excepcional cuya finalidad es ampliar retroactivamente el derecho a la pensión de viudedad, si bien no para cualquier supuesto de pareja de hecho estable, sino solo para situaciones de convivencia more uxorio cualificada; de suerte que la descendencia común no solo se erigiría en el presupuesto mismo de la concreta situación de necesidad que se pretende atender mediante dicha prestación especial - disminución de ingresos producida por el óbito de uno de los miembros de la pareja de hecho-, sino que, a la vez, permitiría evitar reclamaciones abusivas o fraudulentas fundadas en hechos pretéritos de dudosa probanza. De este modo, se pronuncian a favor de la constitucionalidad del precepto legal cuestionado porque el requisito señalado constituye un indicador inequívoco de la existencia efectiva de la relación de convivencia more uxorio que se pretende proteger.

El TC debe determinar si el requisito de haber tenido hijos comunes con el causante, para acceder a la prestación de viudedad respecto de hechos anteriores al 1 de enero de 2008, comporta o no una discrimina- 
ción por razón de la orientación sexual - prohibida por el art. 14 CE-, en tanto que excluye del acceso a dicha prestación a las parejas de hecho del mismo sexo, cuando el hecho causante se haya producido antes de la posibilidad legal de adopción - en el ámbito autonómico o estatal que corresponda - y a partir de esta fecha, lo limita notablemente en comparación con las parejas heterosexuales.

El TC en la sentencia 41/2013, de 14 de febrero, considera que el requisito legal de «haber tenido hijos en común» no puede ser entendido como «un indicador inequívoco de la existencia efectiva de la relación de convivencia more uxorio que se pretende proteger, pues ni la circunstancia de haber tenido hijos en común acredita una mayor estabilidad o solidez de la unión de hecho, ni dicha circunstancia constituye el único medio de prueba posible sobre la estabilidad de la pareja, debiendo repararse en que la propia disposición adicional tercera de la Ley 40/2007, en su letra b), ya establece como requisito autónomo para acceder a la pensión, al margen de la descendencia, que el beneficiario hubiera mantenido convivencia ininterrumpida como pareja de hecho con el causante durante, al menos, los seis años anteriores al fallecimiento de este, en los términos establecidos en el primer inciso, párrafo cuarto, del artículo 174.3 LGSS» (FJ 7..$^{18}$.

En suma, descartado que la diferencia de trato entre parejas de hecho que establece el requisito contenido en la letra c) de la DA 3. . Ley 40/2007 se justifique por la conveniencia de acreditar de forma inequívoca una efectiva y estable convivencia entre el causante y el conviviente beneficiario, se rechaza que dicho requisito encuentre justificación objetiva y razonable en una pretendida finalidad de otorgar protección social a una concreta situación de necesidad ya que puede accederse a la pensión de viudedad excepcional tanto si existen hijos comunes de la pareja de hecho a cargo del supérstite, como si los hijos comunes de la pareja no sobreviven al causante o no se encuentran ya a cargo del supérstite por ser mayores de edad.

Para el TC el requisito de «haber tenido hijos en común» carece de justificación constitucionalmente legítima por dos motivos: en primer lu-

${ }_{18}$ Más aún, tanto en el supuesto excepcional de la pensión de viudedad more uxorio previsto en la DA 3. ${ }^{\mathrm{a}}$ - para hechos causantes antes del 1 de enero de $2008-$, como en el supuesto «ordinario», regulado en el artículo 174.3 LGSS - para los hechos causantes a partir del 1 de enero de 2008-, el cumplimiento del requisito de convivencia estable y notoria como pareja de hecho con carácter inmediato al fallecimiento del causante se acredita del mismo modo - durante un periodo mínimo que es, por cierto, superior en el caso de la pensión de viudedad de carácter excepcional-, mediante el certificado municipal de empadronamiento. 
gar, porque no responde a la finalidad de la pensión (contributiva) de viudedad configurada en la DA 3. ' Ley 40/2007, «que no es propiamente la de atender una situación real de necesidad o de dependencia económica, sino más bien resarcir frente al daño que se produce al actualizarse la contingencia (la muerte del causante), por la falta o minoración de ingresos de los que participaba el supérstite, otorgando a tal efecto una pensión que depende en su cuantía de las cotizaciones efectuadas por el causante al régimen de Seguridad Social correspondiente». En segundo lugar, porque resulta de imposible cumplimiento - la exigencia de haber tenido hijos comunes - por razones biológicas - tanto para las parejas de hecho formadas por personas del mismo sexo como para las parejas de hecho de distinto sexo que no pudieron tener hijos por causa de infertilidad - y por razones jurídicas, ya que la posibilidad de adopción de niños por las parejas de hecho ha estado vetada en nuestro ordenamiento jurídico hasta fechas relativamente recientes - $\left(\text { FJ 8. } .^{\circ}\right)^{19}$. Por estos motivos, la STC de 14 de febrero de 2013 declara la inconstitucionalidad y nulidad de la letra c) de la DA 3. ' por vulneración del principio de igualdad ante la Ley, consagrado en el artículo $14 \mathrm{CE}^{20}$, advirtiendo que no permite reclamar la

${ }^{19}$ La STC analizada cuenta con un Voto particular que formula don Francisco Pérez de los Cobos Orihuel, al que se adhieren don Ramón Rodríguez Arribas, don Andrés Ollero Tassara y don Juan José González Rivas, en virtud del cual el presupuesto de haber tenido descendencia en común como criterio de selección de la situación merecedora de protección no puede considerarse carente de justificación objetiva y razonable, atendidos los limitados recursos económicos del sistema de la Seguridad Social. En su opinión, «haber tenido hijos en común implica la existencia de mayores cargas familiares, anteriores y/o posteriores al hecho causante, cuya atención incide en todo caso sobre la capacidad económica del superviviente. Su valoración, por el legislador, por tanto, encaja perfectamente en la lógica de esta prestación dirigida a compensar el daño que la muerte del causante produce en el beneficiario por la falta o minoración de ingresos de los que participaba, sin que resulte desprovisto de sentido presumir que este daño es mayor cuando han existido hijos comunes. La existencia de hijos comunes no es, por lo demás, un requisito ajeno a la regulación de la pensión de viudedad, pues el legislador lo contempla también en otros supuestos (art. 174.1 in fine LGSS)».

Vid., con más detenimiento, los argumentos alegados por DESDENTADO DAROCA ( $L a$ pensión de viudedad. Retos del Derecho de Familia y reflexiones sobre las últimas reformas, op. cit., pp. 192 a 199) en una línea similar a lo señalado en el Voto particular.

${ }^{20}$ Vid., las SSTC 55/2013, de 11 de marzo y 77/2013, de 8 abril y 188/2014, de 17 de noviembre que estiman los recursos de amparo por vulneración del derecho a la igualdad del artículo $14 \mathrm{CE}$, promovidos por convivientes supérstites a los que se les había denegado la pensión de viudedad, por incumplimiento del presupuesto de «haber tenido hijos en común». Dichas Sentencias reiteran la doctrina expuesta en la STC citada de 14 de febrero de 2013, donde se declara la inconstitucionalidad de dicho presupuesto, para el acceso a la pensión de viudedad. 
pensión a aquellos que por no cumplir el requisito de «haber tenido hijos en común», no la solicitaron en el plazo de doce meses siguientes a la entrada en vigor de dicha $\mathrm{Ley}^{21}$; tampoco permite revisar procesos fenecidos mediante sentencia con fuerza de cosa juzgada en los que se haya hecho aplicación de lo dispuesto en dicha letra c).

\section{LA «CONSIDERACIÓN» Y «ACREDITACIÓN» DE LAS PAREJAS DE HECHO EX ARTÍCULO 174.3 LGSS: EL PROBLEMA DE LA REMISIÓN A LAS LEYES DE PAREJAS DE HECHO EN LAS COMUNIDADES AUTONÓMAS CON COMPETENCIA EN DERECHO CIVIL}

Como se ha señalado, la Ley 40/2007 MMSS reconoce con carácter general la pensión de viudedad a las parejas de hecho, a partir del 1 de enero de 2008. Para ello, el artículo 174.3 LGSS exige que el conviviente supérstite pruebe el cumplimiento de una serie de requisitos: alta, cotización, dependencia económica respecto del fallecido y que haya formado una pareja de hecho. El presupuesto más debatido ha sido el concerniente a la formación de la pareja de hecho ya que ante la falta de una ley estatal de parejas de hecho, que regulase los presupuestos de constitución y acreditación, el legislador de la Seguridad Social adoptó la decisión de establecer dos vías de acceso distintas en función de si la Comunidad Autónoma, en la que residían los convivientes more uxorio, contaba o no con competencia en materia de Derecho civil.

La primera vía de acceso es para los que viven en CCAA sin competencia en materia de Derecho civil ${ }^{22}$. El párrafo $4 .^{\circ}$ del artículo 174.3

${ }^{21}$ Para Moreno Gené, J., («"Pensión especial de viudedad” para parejas de hecho sin hijos comunes», Revista doctrinal Aranzadi Social, n. ${ }^{\circ}$ 2, 2013 (BIB 2013, 944), p. 5) dicha exigencia - solicitud de la pensión de viudedad en el plazo improrrogable de los doce meses siguientes a la entrada en vigor de la Ley 40/2007 - «va a comportar que a pesar de la declaración de inconstitucionalidad y nulidad del requisito de tener hijos comunes para acceder a la "pensión especial" de viudedad de las parejas de hecho, quienes no presentaron la solicitud a la misma por no cumplir con el requisito ahora anulado de tener hijos comunes, no podrán acceder ahora a la misma, pese a cumplir con el resto de requisitos. Lo mismo sucede con quienes a pesar de haber solicitado la "pensión especial" de viudedad vieron denegada su solicitud en vía administrativa e, incluso, en vía judicial mediante sentencia con fuerza de cosa juzgada, por no cumplir la exigencia de tener hijos comunes».

${ }^{22}$ Cfr., la Ley 11/2001, de 19 de diciembre, de Uniones de Hecho de la Comunidad de Madrid (BOE n. ${ }^{\circ}$ 55, de 5 de marzo de 2002); Ley 1/2001, de 6 de abril, por la que se regulan las uniones de hecho de la Comunidad Valenciana (BOE n. ${ }^{\circ} 112$, de 10 
LGSS establece que «(...) se considerará pareja de hecho la constituida, con análoga relación de afectividad a la conyugal, por quienes, no hallándose impedidos para contraer matrimonio, no tengan vínculo matrimonial con otra persona y acrediten, mediante el correspondiente certificado de empadronamiento, una convivencia estable y notoria con carácter inmediato al fallecimiento del causante y con una duración ininterrumpida no inferior a cinco años. La existencia de pareja de hecho se acreditará mediante certificación de la inscripción en alguno de los registros específicos existentes en las comunidades autónomas o ayuntamientos del lugar de residencia o mediante documento público en el que conste la constitución de dicha pareja. Tanto la mencionada inscripción como la formalización del correspondiente documento público deberán haberse producido con una antelación mínima de dos años con respecto a la fecha del fallecimiento del causante».

Como puede comprobarse, se exigen dos presupuestos simultáneos para que el miembro supérstite de la unión pueda obtener la susodicha pensión: (i) la convivencia como pareja de hecho estable y notoria durante un periodo mínimo de cinco años inmediatamente anteriores al fallecimiento del causante, acreditada mediante el correspondiente certificado de empadronamiento ${ }^{23}$; y (ii) la verificación de que la pareja de hecho se ha constituido como tal mediante la correspondiente inscripción en el Registro de parejas de hecho (en alguno de los registros específicos existentes en las CCAA o Ayuntamientos del lugar de residencia) o en documento público, con dos años de antelación a la fecha del fallecimiento del causante.

de mayo de 2001); Ley 4/2002, de 23 de mayo, de Parejas estables de la Comunidad Autónoma del Principado de Asturias (BOE n. . 157, de 2 de julio de 2002); Ley 5/2002, de 16 de diciembre, de Parejas de Hecho de la Comunidad Autónoma de Andalucía (BOE n. ${ }^{\circ} 11$, de 13 de enero de 2003); Ley 5/2003, de 6 de marzo, para la regulación de las parejas de hecho en la Comunidad Autónoma de Canarias (BOC n. ${ }^{\circ}$ 54, de 19 de marzo de 2003); Ley 5/2003, de 20 de marzo, de Parejas de Hecho de la Comunidad Autónoma de Extremadura (DOE n. . 42, de 8 de abril de 2003); Ley 1/2005, de 16 de mayo, de parejas de hecho de la Comunidad Autónoma de Cantabria (BO Cantabria n. ${ }^{\circ} 98$, de 16 de mayo de 2005).

${ }^{23}$ De una interpretación literal de este presupuesto se llega a la conclusión de que no se devengaría la pensión de viudedad en el caso de que la pareja no estuviera empadronada, pese a llevar conviviendo más de los cinco años, exigidos por el artículo 174.3 LGSS. Para evitar esta situación injusta el TS en las sentencias de 26 de enero de 2011 (RJ 2011, 2115), 14 de abril de 2011 (RJ 2011, 3953) y 9 de junio de 2011 (RJ 2011, 5334), entre otras muchas, viene entendiendo que la «la convivencia more uxorio debe poder acreditarse mediante otros medios de prueba admisibles en Derecho y no exclusivamente mediante el certificado de empadronamiento». 
La otra forma de acceso a la pensión de viudedad era para los convivientes more uxorio que residían en alguna de las CCAA con Derecho civil propio. El párrafo $5 .^{\circ}$ del artículo 174.3 LGSS señalaba - antes de su declaración de inconstitucionalidad y nulidad por la STC 40/2014, de 11 de marzo - que «en las Comunidades Autónomas con Derecho civil propio, cumpliéndose el requisito de convivencia a que se refiere el párrafo anterior, la consideración de pareja de hecho y su acreditación se llevará a cabo conforme a lo que establezca su legislación específica» ${ }^{24}$. La remisión legal efectuada no es a todas las legislaciones existentes sobre parejas de hecho sino únicamente a aquellas promulgadas en CCAA con competencia en materia de Derecho civil - ex art. 149.1.8. ${ }^{\circ} \mathrm{CE}-\mathrm{y}$ en lo relativo a la «consideración» $\mathrm{y}$ «acreditación» de las uniones de hecho. El legislador de la Seguridad Social aceptaba que dentro de una norma básica de la Seguridad Social - art. 174.3 LGSS - se estableciera una diferenciación por razón del territorio, en virtud del principio constitucional de autonomía $e x$ artículos 2, 137 y concordantes de la CE; bien, es cierto, que de alcance limitado, pues tal divergencia se refería exclusivamente a la definición y acreditación de la pareja de hecho, mientras mantenía el requisito de la convivencia quinquenal y los demás determinantes de la adquisición o conservación del derecho a la pensión en términos de perfecta uniformidad para todo el territorio español.

Sin ánimo de ser exhaustivos, en lo relativo a la «consideración» de pareja de hecho se aprecia algún matiz distinto entre el pár. $4 .^{\circ}$ del artículo 174.3 LGSS y la regulación de las CCAA con Derecho civil propio. Para el legislador de la Seguridad Social la pareja de hecho es «la constituida, con análoga relación de afectividad a la conyugal, por quienes, no hallándose impedidos para contraer matrimonio, no tengan vínculo matrimonial». De acuerdo con lo establecido en los artículos 46 y $47 \mathrm{del}$ $\mathrm{CC}$ no pueden contraer matrimonio los menores de edad no emancipados, los que están ligados con vínculo matrimonial, los parientes en línea recta por consanguinidad o adopción, los colaterales por consanguinidad hasta el tercer grado y los condenados como autores o cómplices de la muerte dolosa del cónyuge de cualquiera de ellos. Pues bien, ninguna de las normas sobre parejas de hecho de las Comunidades Autónomas con Derecho civil propio recoge este último impedimento y por lo que se refiere a los colaterales por consanguinidad algunas de dichas normas

${ }^{24}$ El párrafo se incluyó durante la tramitación de la Ley 40/2007 en la fase de enmiendas en el Senado por parte del Grupo Parlamentario Catalán y por Esquerra Republicana de Catalunya. 
jurídicas impiden constituir una pareja de hecho a los colaterales hasta el segundo grado ${ }^{25}$ y otras los amplían a los colaterales por adopción ${ }^{26}$.

Con la «acreditación» de la pareja de hecho también se observan algunas diferencias significativas entre las formas previstas en el pár. $4 .^{\circ}$ del artículo 174.3 LGSS, pareja de hecho formalizada «mediante certificación de la inscripción en alguno de los registros específicos existentes en las comunidades autónomas o ayuntamientos del lugar de residencia o mediante documento público en el que conste la constitución de dicha pareja» y las legislaciones sobre parejas de hecho de las CCAA con Derecho civil propio. Es cierto que existen algunas CCAA con competencia en materia de Derecho civil que admiten la verificación de las parejas de hecho a través de las inscripciones realizadas - con carácter constitutivo- en alguno de los registros específicos existentes ${ }^{27}$; no obstante, existen otras CCAA con Derecho foral que han establecido otras formas de acreditación. En este sentido, el Decreto Legislativo 1/2011, de 22 de marzo, por el que aprueba el Código del Derecho foral de Aragón establece en el artículo 305 que la existencia de una pareja estable no casada puede acreditarse, si no existiera escritura pública, mediante cualquiera de los medios de prueba admitidos en derecho, especialmente a través de acta de notoriedad o documento judicial que acredite la convivencia. También, la Ley foral 6/2000, de 3 de julio, para la igualdad jurídica de las parejas estables, establece en su artículo 3 que la existencia de la pareja estable podrá acreditarse a través de cualquier medio de prueba admitido en Derecho ${ }^{28}$. En sentido similar la Ley 25/2010, de 29 de julio,

${ }^{25}$ Vid., en este sentido, el artículo 2.1 de la Ley foral 6/2000, de 3 de julio, para la igualdad jurídica de parejas estables de Navarra; el artículo 306 del Decreto Legislativo 1/2011, de 22 de marzo, por el que se aprueba el Código del Derecho foral de Aragón; el artículo 234.2 de la Ley 25/2010, de 29 de julio, por el que se aprueba el Código civil de Cataluña; el artículo 2 de la Ley del País Vasco 2/2003, de 7 de mayo, reguladora de las parejas de hecho; y el artículo 4 de la Ley 5/2012, de 15 de octubre, de uniones de hecho formalizadas de la Comunidad Valenciana).

${ }^{26}$ Cfr., el artículo 306 del Decreto Legislativo 1/2011, de 22 de marzo, por el que se aprueba el Código del Derecho foral de Aragón; la disposición adicional tercera de la Ley 2/2006, de 14 de junio, de Derecho civil de Galicia; y el artículo 4 de la Ley 5/2012, de 15 de octubre, de uniones de hecho formalizadas en la Comunidad Valenciana.

${ }^{27}$ Vid., en este sentido, el artículo 1.2 de la Ley 18/2001, de 19 de diciembre, de parejas estables de las Islas Baleares; el artículo 3.1 de la Ley del País Vasco 2/2003, de 7 de mayo, reguladora de las parejas de hecho; la disposición adicional tercera de la Ley 2/2006, de 14 de junio, de Derecho civil de Galicia; y el artículo 3 de la Ley 5/2012, de 15 de octubre, de uniones de hecho formalizadas de la Comunidad Valenciana.

${ }^{28} \mathrm{Al}$ artículo 3 se le reprocha que, al permitir que la existencia de la pareja estable pueda ser acreditada por cualquier medio de prueba admitido en derecho, vulnera, por 
del libro segundo del Código Civil de Cataluña, relativo a la persona y a la familia, establece que, para acreditar la existencia de una pareja de hecho, basta con demostrar por cualquier medio de prueba la convivencia ininterrumpida de la pareja durante dos años, no siendo ni siquiera necesario acreditar periodo alguno de convivencia cuando la pareja hubiere tenido hijos en común o si la relación se hubiere formalizado en escritura pública.

De la contraposición efectuada entre los párrafos $4 .^{\circ}$ y $5 .^{\circ}-$ que a su vez remitía a las leyes de parejas de hecho, dictadas por CCAA con Derecho civil propio - del artículo 174.3 LGSS, se observa que no existe un tratamiento jurídico unitario en lo relativo a la «consideración» y «acreditación» de las uniones more uxorio. Esas diferencias conspicuas entre convivientes españoles, en función del lugar en que residían, lleva a que la Sala de lo Social del TS plantee una cuestión de inconstitucionalidad mediante el Auto de 14 de diciembre de $2011^{29}$.

Los hechos, que dan lugar al Auto indicado, son los siguientes: tras la denegación por el INSS de la pensión de viudedad, solicitada por una conviviente - con vecindad civil asturiana - , al entender que no había acreditado la constitución formal de la pareja de hecho, esta interpone demanda ante el Juzgado de lo Social, n. ${ }^{\circ} 4$ de Gijón. Desestimada la demanda por sentencia de 30 de septiembre de 2009, recurre en suplicación ante la Sala de lo Social del TSJ de Asturias. En el recurso alegaba que en las CCAA con Derecho civil propio la consideración de pareja de hecho y su acreditación se llevaba a efecto conforme a lo que establecía su legislación específica, por lo que al contar el Principado de Asturias de un Derecho civil propio, aunque sea de naturaleza consuetudinaria, había de aplicarse el pár. 5. ${ }^{\circ}$ del artículo 174.3 LGSS que remitía a la legislación autonómica sobre parejas de hecho; en concreto,

su inconcreción el principio de seguridad jurídica. Sin embargo, el TC en la Sentencia 93/2013, de 23 de abril, señala que conforme a su doctrina jurisprudencial sobre el principio de seguridad jurídica no puede admitirse que el artículo 3 vulnere dicho principio, «ya que la norma no genera incertidumbre de ninguna clase que contraríe el principio de seguridad jurídica previsto en el artículo 9.3 CE (RCL 1978, 2836), pues se trata de una previsión legal clara en sus términos que, por lo demás, no resulta desconocida en numerosos ámbitos de nuestro ordenamiento jurídico. En todo caso, parece que lo que preocupa (...) es el mal uso que se pueda hacer de esa norma y que pueda dar lugar a situaciones de fraude, argumento que en modo alguno puede justificar su inconstitucionalidad, correspondiendo a su aplicador y, en último término, a los Tribunales de justicia, determinar si los medios de prueba de que intenten valerse los interesados resultan o no admisibles, y si de ellos se puede concluir la presencia efectiva de una unión estable» (FJ 10. ${ }^{\circ}$ ).

${ }^{29}$ RJ 2011, 3497. 
la Ley del Principado de Asturias 4/2002, de 23 de mayo, de parejas estables, en su artículo 3 señala que son uniones de hecho aquellas que han convivido maritalmente como mínimo un periodo ininterrumpido de un año, pudiendo ser acreditada la convivencia por medio de cualquier medio de prueba admitido en Derecho. En definitiva, al no exigir necesariamente la citada legislación autonómica la inscripción en el Registro de Uniones de Hecho, para acreditar la existencia de tal unión y habiendo quedado acreditada tal convivencia, la actora entendía que tenía derecho a la pensión de viudedad reclamada.

El recurso fue desestimado por dicha Sala en la sentencia de 23 de abril de 2010, confirmando lo dicho en la instancia, al considerar incumplido por la actora el requisito de constitución formal de la pareja de hecho. A mayor abundamiento, señala la Sala en su FJ 4. . que, al carecer el Principado de Asturias de un Derecho civil propio, la recurrente debía regirse por el régimen general previsto en el artículo 174.3.4. ${ }^{\circ}$ LGSS que exigía con carácter obligatorio la constitución formal de la pareja de hecho - mediante inscripción en alguno de los Registros de parejas o por documento público- - . Por consiguiente, conforme a la doctrina de esa Sala, la referencia del artículo 174.3 LGSS a las CCAA con Derecho civil propio quedaba limitada a las CCAA con Derecho foral, no siendo este el caso del Principado de Asturias; por lo que se desestima la pretensión de la recurrente de poder acreditar la existencia de la pareja de hecho estable a través de cualquier medio de prueba, en aplicación de lo dispuesto en la Ley autonómica asturiana.

Contra dicha resolución judicial la actora formula recurso de casación ante la Sala de lo Social del TS para la unificación de doctrina, en el que se alegaba como sentencia contradictoria con la recurrida la dictada por la Sala de lo Social del Tribunal Superior de Justicia de Aragón de fecha de 9 de marzo de 2009. En esta última sentencia se confirmaba la sentencia de instancia y se concedía la pensión de viudedad a la recurrente - que se encontraba en una situación idéntica a la recurrente de la sentencia dada por el TSJ de Asturias - , basándose en la siguiente argumentación jurídica: «(...) ha reconocido a la actora la pensión de viudedad que reclamaba por considerar que, aun no figurando inscrita su unión de hecho con el fallecido D. Eduardo en registro específico alguno ni haberse constatado dicha unión en documento público, en los términos en que dicho requisito alternativo viene configurado por el párrafo cuarto del artículo 174.3 de la Ley General de la Seguridad Social, sin embargo se ha acreditado fehacientemente por los medios de prueba aportados al proceso la convivencia more uxorio de ambos desde 1979, cumpliéndose por tanto en el presente caso la exigencia que en 
orden a la "acreditación" de la pareja de hecho viene establecida en la Ley, habida cuenta de la remisión que realiza el párrafo quinto del comentado artículo 174.3 a la legislación particular de las comunidades autónomas con Derecho civil propio, como es el caso de Aragón. En el caso litigioso esta legislación autonómica es la constituida por la mencionada Ley 6/1999 (LARG 1999, 79), cuyo artículo 3.2, intitulado "existencia de pareja estable no casada" dispone: "Podrá acreditarse la existencia de pareja estable no casada..., si no existiera escritura pública, mediante cualquiera de los medios de prueba admitidos en derecho..."» (FJ 1. $\left.{ }^{\circ}\right)$.

La Sala de lo Social del TS, reunida en Pleno, tenía que pronunciarse sobre cómo debía interpretarse la remisión contenida en el pár. 5 . $^{\circ}$ del artículo 174.3 LGSS, cuando se trataba de una persona con vecindad civil en una CA - como la asturiana - que carece de Derecho civil propio. Si el TS realizaba una interpretación flexible y entendía que la remisión era a las leyes de parejas de hecho, a la recurrente se le aplicaría la Ley 4/2002, de 23 de mayo, de Parejas Estables de Asturias, cuyo artículo 3.3 dispone que la existencia de la pareja estable o el transcurso de un año de convivencia de la misma - que también se exige - «podrán acreditarse a través de cualquier medio de prueba admitido en Derecho». Con este planteamiento la recurrente obtendría la pensión de viudedad, puesto que en el caso de autos son múltiples las pruebas que acreditan la existencia de la pareja de hecho que constituyó con el causante fallecido, entre ellas la de tener descendencia en común - dos hijos - y la de estar empadronados en el mismo domicilio desde el 1 de mayo de 1996 y, según el artículo 3.3 de la ley asturiana citada, cualquiera de ellas es suficiente para tal acreditación, pese a no haberse practicado ni inscripción en el Registro de parejas de hecho ni otorgamiento de documento público. La doctrina jurisprudencial quedaría así unificada, puesto que en la sentencia de contraste - STSJ de Aragón de 9 de marzo de 2009- la viuda sí obtuvo la pensión de viudedad, al resultarle de aplicación la Ley de Parejas Estables no casadas de Aragón ex artículo 3.2 citado anteriormente. Por el contrario, si realizaba una interpretación literal del pár. 5. ${ }^{\circ}$ del artículo 174.3 LGSS, la viuda no obtendría la pensión de viudedad ya que no se aplicaría el párrafo señalado al supuesto de hecho debatido sino el pár. $4 .^{\circ}$ del mismo precepto legal, que exige necesariamente la inscripción en el Registro de parejas o un documento público para la acreditación de la pareja de hecho.

La Sala Cuarta del TS por medio del Auto mencionado de 14 de diciembre de 2011 considera en su FJ 7. ${ }^{\circ}$ que «(...) dado que el tenor literal del artículo 174.3, párrafo quinto de la LGSS (RCL 1994, 1825) 
es terminante: «En las Comunidades Autónomas con Derecho civil propio» - y solamente en ellas, entiende esta Sala - se aplica su legislación específica, consistente - eso sí- en sus respectivas leyes de parejas de hecho. Esta Sala entiende que, por más que se agoten los márgenes de la interpretación flexible, no se puede tener por no puesta la mención que el legislador - con acierto o sin él - ha hecho al Derecho Civil propio de ciertas Comunidades Autónomas. Por lo tanto (...) a la recurrente no se le aplica su legislación específica [la ley asturiana 4/2002, de 23 de mayo (LPAS 2002, 154), de Parejas Estables] sino que se le aplica la regla general del artículo 174.3 párrafo cuarto de la LGSS». Con la interpretación del párrafo discutido, que mantiene el TS, la viuda recurrente no obtendría la pensión de viudedad solicitada ya que el precepto aplicable al supuesto de hecho es el pár. $4 .^{\circ}$ del artículo 174.3 LGSS, que exige ineludiblemente la acreditación de la existencia de la pareja de hecho mediante certificación de la inscripción en algunos de los registros específicos existentes en las Comunidades Autónomas o ayuntamientos del lugar de residencia o mediante documento público. Por el contrario, otra persona, que estuviera en las mismas circunstancias pero en una Comunidad Autónoma - como la de Aragón - con competencia en materia de Derecho civil, sí puede acogerse a su Ley de parejas estables no casadas y obtener la pensión de viudedad, pese a no estar inscrita en el registro correspondiente o en documento público.

La Sala Cuarta del TS, consciente de que la aplicación del precepto da lugar a una diferencia de trato de difícil justificación entre ciudadanos españoles por razón de tener una vecindad civil distinta, eleva una cuestión de inconstitucionalidad, al planteársele dos dudas de constitucionalidad relacionadas entre sí respecto del contenido del pár. 5. ${ }^{\circ}$ del artículo 174.3 LGSS: la posible vulneración de los artículos 14 y 149.1.17 CE. Por un lado, se pregunta por la posible infracción del principio de igualdad ante la ley en el acceso a la pensión de viudedad, al establecer para ciertas Comunidades Autónomas - por vía de remisión a su legislación específica - una regulación sobre la existencia y acreditación de las parejas de hecho, que difiere de la regla general contenida en el párrafo $4 .^{\circ}$. Por otro, si de la remisión, que efectúa la norma cuestionada, al Derecho civil propio de las CCAA podría infringirse el artículo 149.1.17 CE - que atribuye al Estado la competencia exclusiva sobre la legislación básica y el régimen económico de la Seguridad Social-, al tratarse la pensión de viudedad de una prestación de la Seguridad Social, fundamentada en los «principios de universalidad, unidad, solidaridad e igualdad» (art. 2.1 LGSS). En suma, se cuestiona si la diferencia de trato 
aludida, derivada del susodicho precepto, supera o no el canon de constitucionalidad; en otros términos, si la diferencia de trato se encuentra justificada por ser objetiva, razonable y proporcionada.

Por último, el Auto mencionado de 14 de diciembre de 2011 del TS va más lejos aún y en el FJ $8 .^{\circ}$ plantea dos maneras de eliminar la posible desigualdad que se deriva de la aplicación del pár. 5. del artículo 174.3 LGSS. La primera de ellas consiste en declarar nulo por inconstitucional el párrafo quinto del artículo 174.3 LGSS, dejando solamente en vigor la regla general del párrafo cuarto, que quedaría como regla única para todo el Estado español. La otra alternativa sería efectuar una declaración parcial de inconstitucionalidad del pár. 5. ${ }^{\circ}$ cuestionado, que llevara a declarar que la alusión al Derecho civil propio de ciertas Comunidades Autónomas resulta nula por inconstitucional, dado que de ella se desprende una inevitable violación del principio de igualdad. Limitada la nulidad a esa única referencia, la remisión que la norma hace a la legislación específica de las Comunidades Autónomas se entendería realizada a las leyes autonómicas sobre las parejas de hecho, hoy existentes en la práctica totalidad de las Comunidades Autónomas - salvo Murcia y La Rioja, a las que nada impide adoptar tal tipo de legislación en un futuro-; de modo que la regla general del pár. $4 .^{\circ}$ quedaría como regla subsidiaria para el caso excepcional de inexistencia de legislación autonómica específica sobre parejas de hecho. Reconoce la Sala que esta segunda opción no impediría la posible desigualdad dimanante de la propia diversidad de las leyes autonómicas sobre parejas de hecho, por lo que el TC habría de valorar si esa desigualdad es razonable $-\mathrm{y}$, por tanto, respetuosa con el art. $14 \mathrm{CE}-$, por constituir una consecuencia lógica del principio de autonomía política o, si por el contrario, no lo es, al encontrarse en el ámbito de la legislación básica de la Seguridad Social, que es competencia exclusiva del Estado y debe estar presidida por el principio de igualdad de manera, si cabe, reforzada.

\section{La declaración de inconstitucionalidad total y nulidad del párrafo 5. ${ }^{\circ}$ del artículo 174.3 LGSS por la STC 40/2014}

Planteada la cuestión de inconstitucionalidad por posible discriminación entre los convivientes de hecho, al establecerse para las CCAA con Derecho civil propio - por la remisión que el pár. $5 .^{\circ}$ del art. 174.3 LGSS realiza a su legislación específica - una regulación sobre los requisitos de acceso a la pensión de viudedad, que difiere de la regla general contenida en el pár. $4 .^{\circ}$ del mismo precepto legal, el TC exami- 
na la cuestión suscitada desde la perspectiva de la cláusula general de igualdad. En relación a esta materia puede consultarse la doctrina seguida por el TC en la sentencia 41/2013, de 14 de febrero: «(...) como tiene declarado este Tribunal desde la STC 22/1981, de 2 de julio (recogiendo al respecto la doctrina del Tribunal Europeo de Derechos Humanos en relación con el artículo 14 del Convenio europeo para la protección de los derechos humanos y de las libertades fundamentales), el principio de igualdad no implica en todos los casos un tratamiento legal igual con abstracción de cualquier elemento diferenciador de relevancia jurídica, de manera que no toda desigualdad de trato normativo respecto a la regulación de una determinada materia supone una infracción del mandato contenido en el artículo $14 \mathrm{CE}$, sino tan solo las que introduzcan una diferencia entre situaciones que puedan considerarse iguales, sin que se ofrezca y posea una justificación objetiva y razonable para ello, pues, como regla general, el principio de igualdad exige que a iguales supuestos de hecho se apliquen iguales consecuencias jurídicas y, en consecuencia, veda la utilización de elementos de diferenciación que quepa calificar de arbitrarios o carentes de una justificación razonable» ( $\left.\mathrm{FJ} 6 .^{\circ}\right)$.

Así entendido, para que la diferencia de trato sea constitucionalmente lícita, las consecuencias jurídicas, derivadas de tal distinción, deben ser proporcionadas a la finalidad perseguida, de manera que se eviten resultados excesivamente gravosos o desmedidos. El principio de igualdad ante la ley no solo exige que la diferencia de trato resulte objetivamente justificada, sino también que supere un juicio de proporcionalidad sobre la relación existente entre la medida adoptada, el resultado producido y la finalidad pretendida ${ }^{30}$. Aplicando esta doctrina, la actuación del TC se centra en determinar si la diferencia de trato, establecida en el pár. 5..$^{\circ}$ del artículo 174.3 LGSS, entre parejas de hecho con residencia en CCAA con Derecho civil propio - que hubieran aprobado legislación específica en materia de uniones de hecho- y parejas de hecho con residencia en CCAA sin competencia en materia de Derecho civil responde a una finalidad objetivamente justificada, razonable y proporcionada; sin olvidar que la pensión de viudedad es una

30 Vid., en este sentido, las sentencias del TC 22/1981, de 2 de julio, en su FJ 3. ${ }^{\circ}$; 49/1982, de 14 de julio, en su FJ 2..$^{\circ}$; $2 / 1983$, de 24 de enero en su FJ 4..$^{\text {; }}$ 23/1984, de 20 de febrero, en su FJ 6. ${ }^{\circ}$; 209/1987, de 22 de diciembre, en su FJ $3 .^{\circ}$; 209/1988, de 10 de noviembre, en su FJ 6. ${ }^{\circ}$; 20/1991, de 31 de enero, en su FJ $2 .^{\circ}$; 340/1993, de 16 de noviembre, en su FJ $4 .^{\circ}$; 117/1998, de 2 de junio, en su FJ $8 .^{\circ}$; 200/2001, de 4 de octubre, en su FJ 4. ${ }^{\circ}$; 39/2002, de 14 de febrero, en su FJ 4. ${ }^{\circ}$, entre otras. 
prestación de la Seguridad Social, respecto de la cual el Estado tiene competencia exclusiva ex artículo 149.1.17 CE.

El TC en el FJ 4. ${ }^{\circ}$ de la sentencia citada de 11 de marzo de 2014 llega a la conclusión de que la diferencia de trato, en cuanto al acceso a la pensión de viudedad en función del lugar de residencia, carece de justificación objetiva ya que las parejas de hecho de las CCAA con Derecho civil propio no se encuentran en una situación de necesidad particular que obligue a establecer excepciones ${ }^{31}$ a la regla general, contenida en el pár. 4..$^{\circ}$ del artículo 174.3 LGSS ${ }^{32}$. En su opinión, «(...) en el caso de la pensión de viudedad, las diferencias en función del criterio de residencia en una u otra Comunidad Autónoma no gozan de esa justificación objetiva, por cuanto no se aprecian razones para deducir que

${ }^{31}$ Partidario de la existencia de una justificación objetiva se había pronunciado el TC en la sentencia 90/1989, de 11 de marzo, en materia de prestaciones de la Seguridad Social y en concreto en relación con el subsidio de desempleo para trabajadores eventuales solo en Andalucía y Extremadura: «(...) la situación de necesidad y las perspectivas en orden a su remedio o agravación pueden verse afectadas por el contexto territorial en que se produzcan» $\left(\mathrm{FJ} 4 .^{\circ}\right)$.

32 Por su parte, los magistrados doña Encarnación Roca Trías y don Juan Antonio Xiol Ríos en el Voto particular que formulan a la STC de 11 de marzo de 2014 se muestran contrarios a la declaración de inconstitucionalidad del segundo inciso del artículo 174.3 LGSS por vulneración del principio de igualdad. En opinión de dichos magistrados, son las CCAA con Derecho civil propio a quienes corresponde regular este tipo de uniones, basándose en el argumento de que la configuración del ordenamiento jurídico civil español como un sistema plural no ha sido considerada inconstitucional, ni contraria al principio de igualdad por parte del Tribunal Constitucional. «De este modo, la remisión efectuada por el artículo cuestionado a la legislación específica de las Comunidades Autónomas de Derecho civil propio no produce una desigualdad contraria al artículo $14 \mathrm{CE}$, puesto que se remite al estatuto jurídico de la pareja de hecho aplicable según su vecindad civil» (vid., la segunda razón del punto 3 del voto particular). Más aún, llegan a decir que «la falta de Derecho civil propio no impedirá a las parejas de hecho de otras Comunidades Autónomas acceder a la pensión de viudedad, mediante el cumplimiento de los requisitos exigidos en el artículo 174.3 LGSS. La desigualdad se produciría si estas parejas no pudieran acceder a la pensión por carecer la Comunidad Autónoma donde se hallan domiciliadas de Derecho civil propio, pero no cuando se aplica este Derecho para determinar quiénes tienen derecho a obtener dicha pensión y se aplican las reglas de su Derecho en la constitución y la acreditación de la pareja, que conforman su estatuto jurídico» (vid., con más detenimiento, las razones $2 .^{\text {a }}$ y 3 . $^{\text {a }}$ del punto 3 del voto particular).

En suma, entienden que la forma más fácil de resolver la cuestión de inconstitucionalidad planteada hubiera sido, manteniendo la vigencia de pár. $5 .^{\circ}$ del artículo 174.3 LGSS, ya que la conviviente de hecho demandante residía en la CA de Asturias que no cuenta con Derecho civil propio, por lo que tendría que haber acreditado los requisitos generales establecidos en el pár. $4 .^{\circ}$ de dicho precepto, si quería conseguir la pensión de viudedad. 
la situación de necesidad en relación a esta prestación es mayor o más grave en las Comunidades Autónomas con Derecho civil propio».

Con este planteamiento jurisprudencial, llega a la conclusión de que todos los presupuestos de acceso a una prestación pública - como es la pensión de viudedad - deben ser iguales para los convivientes que actualicen la contingencia correspondiente, ya que el régimen público de la Seguridad Social debe ser único y unitario para todos los ciudadanos (art. $41 \mathrm{CE}$ ) y debe garantizar al tiempo la igualdad de todos los españoles en el ejercicio de los derechos y deberes en materia de Seguridad Social, siendo ambos aspectos responsabilidad del Estado ${ }^{33}$ en los términos del artículo 149.1.17 CE. Por consiguiente, en opinión del TC, «(...) la determinación de los sujetos beneficiarios de una prestación de la Seguridad Social, en este caso la pensión de viudedad, constituye una norma básica que corresponde establecer al Estado ex artículo 149.1.17 CE y debe hacerlo de forma unitaria para todos los sujetos comprendidos dentro de su ámbito de cobertura, salvo razones excepcionales debidamente justificadas y vinculadas a la situación de necesidad que se trata de proteger. Es claro a este respecto que, en principio, el artículo 149.1.17 CE demanda la fijación de los requisitos y del régimen jurídico de las prestaciones del Sistema de Seguridad Social, de tal forma que el deber de fijar de modo uniforme los requisitos de acceso a la pensión de viudedad forma parte del contenido que protege el citado precepto constitucional».

En suma, el TC en la sentencia aludida de 11 de marzo de 2014 se pronuncia partidario de la uniformidad de los requisitos de acceso a la pensión de viudedad de los convivientes de hecho - con independencia de la vecindad civil que tengan - , por lo que mantiene la regla establecida en el pár. $4 .^{\circ}$ del artículo 174.3 LGSS como la única aplicable a todo el Estado español ${ }^{34}$. Además, como consecuencia de este planteamiento

${ }^{33}$ El régimen público de la Seguridad Social se configura como una función de Estado destinada a garantizar la asistencia y prestaciones suficientes en situaciones de necesidad y al hacerlo debe asegurar la uniformidad de las pensiones en todo el territorio nacional. En este sentido, cfr. el artículo 2.1. LGSS: «el Sistema de la Seguridad Social, configurado por la acción protectora en sus modalidades contributiva y no contributiva, se fundamenta en los principios de universalidad, unidad, solidaridad e igualdad».

${ }^{34}$ Respecto de la otra alternativa planteada por la Sala 4. ${ }^{\text {a }}$ del TS en el Auto de 14 de diciembre de 2011, en virtud de la cual la remisión del pár. 5. a la legislación específica de las CCAA con Derecho civil propio debe entenderse hecha a las leyes de parejas de hecho de las CAAA tengan o no las mismas Derecho civil propio, el TC - en una posición similar a la planteada por dicha Sala 4. ${ }^{a}$ del TS - reconoce que de aceptarse esta solución persistiría la desigualdad dimanante de la propia diversidad de esas leyes autonómicas de parejas de hecho. Para el TC «(...) el problema de fondo que el precepto cuestionado plantea no es la limitación de la remisión a las Comunidades Autónomas con 
jurisprudencial estima la cuestión de inconstitucionalidad planteada, declarando la inconstitucionalidad total y nulidad del párrafo $5 .^{\circ}$ por vulneración del artículo 14 en relación con el artículo 149.1.17, ambos de la CE. A partir de ahora no cabrá ya remisión alguna a la legislación civil de las parejas de hecho, aprobada por las Comunidades Autónomas con Derecho civil propio, en lo relativo a «la consideración de la pareja de hecho y su acreditación», ya que dicha remisión genera desigualdad entre los ciudadanos españoles en el acceso a la pensión de viudedad.

Por último, el TC se pronuncia acerca de la modulación del alcance de la declaración de inconstitucionalidad y nulidad del pár. 5. 'que deberá extenderse a las posibles situaciones administrativas firmes, de suerte que esta declaración de inconstitucionalidad solo será eficaz pro futuro, en relación con nuevos supuestos o con los procedimientos administrativos y procesos judiciales donde aún no haya recaído una resolución firme ${ }^{35}$.

\section{La declaración de inconstitucionalidad del párrafo $5 .^{\circ}$ del artículo 174.3 LGSS y la competencia autonómica del artículo $149.1 .8 .^{a} \mathrm{CE}$}

Llegados a este punto, la cuestión que cabe dilucidar es si la declaración de inconstitucionalidad del párrafo 5. . del artículo 174.3 LGSS

Derecho civil propio, sino la remisión a la legislación autonómica en sí misma cuando se trata de determinar los requisitos de acceso a una prestación de la Seguridad Social. En consecuencia, las conclusiones alcanzadas en el examen de constitucionalidad del inciso del precepto cuestionado - acreditación de la pareja de hecho-, deben extenderse por vía de conexión o consecuencia, en virtud del artículo 39.1 de la Ley Orgánica del Tribunal Constitucional (LOTC), a todo el párrafo quinto del artículo 174.3 LGSS» (FJ 6. ${ }^{\circ}$ ).

${ }_{35}$ Sin carácter exhaustivo, $c f r$. cómo el Pleno del TC, por providencias de 4 de mayo y 4 de junio de 2013, acordó admitir a trámite las cuestiones de inconstitucionalidad números 2253/2013, 2255/2013 y 2256/2013, en relación con los párrafos cuarto y quinto del artículo 174.3 de la LGSS, por posible vulneración de los artículos 14,24.1, 139.1 y 149.1.17 de la CE (BOE de 12 de junio) y por Auto de 7 de abril de 2014 ha declarado la extinción de dichas cuestiones de inconstitucionalidad por desaparición sobrevenida de su objeto (BOE 12 de abril de 2014). En el mismo sentido, por providencia de 24 de septiembre de 2013 admite a trámite las cuestiones de inconstitucionalidad números 4367-2013, 4934-2013 y 4935-2013 en relación con el artículo 174.3, párrafos cuarto y quinto de la LGSS por los mismos motivos (BOE de 7 de octubre) y por Auto de 7 de abril de 2014 declara la extinción de dichas cuestiones de inconstitucionalidad por desaparición sobrevenida de su objeto (BOE 12 de abril de 2014). También por providencia de 11 de febrero de 2014 admite a trámite la cuestión de inconstitucionalidad n. ${ }^{\circ}$ 388-2014, en relación con dicho precepto de la LGSS (BOE de 15 febrero de 2014) y por Auto de 7 abril de 2014 acuerda la extinción de dicha cuestión de inconstitucionalidad por desaparición sobrevenida de su objeto (BOE de 12 de abril de 2014). 
invade la competencia autonómica prevista en el artículo 149.1.8. ${ }^{\mathrm{a}} \mathrm{CE}$, relativa a la «conservación, modificación y desarrollo por las Comunidades Autónomas de los derechos civiles, forales o especiales, allí donde existan $»^{36}$.

El TC, antes de pronunciarse sobre esta cuestión, realiza dos importantes precisiones en el FJ 5.: (i) la norma cuestionada - «en las Comunidades Autónomas con Derecho civil propio, (...) la consideración de pareja de hecho y su acreditación se llevará a cabo conforme a lo que establezca su legislación específica»- relaciona dos planos jurídicos distintos: las competencias autonómicas en materia de derecho civil con la existencia de normas de las CCAA que regulan las parejas de hecho; planos, que en opinión del TC, «no tienen por qué ser coincidentes ni suponen que dichas normas se fundan en la aludida competencia (al respecto, STC 81/2013, de 11 de abril, en relación con la Ley de la Asamblea de Madrid 11/2001, de 19 de diciembre, de uniones de hecho)»; (ii) la diferencia que introduce el pár. $5 .^{\circ}$ del artículo 174.3 LGSS no se vincula estrictamente hablando con la «conservación, modificación y desarrollo por las Comunidades Autónomas de los derechos civiles, forales o especiales allí donde existan» sino con la existencia de legislación reguladora de las parejas de hecho en aquellas Comunidades Autónomas que hubieran asumido estatutariamente dicha competencia en el marco previsto en el artículo 149.1.8 CE y con independencia de cuál sea el contenido material de dicha legislación. Es decir, «la diferenciación que se introduce se formula con independencia de cuál sea el contenido concreto de dicha legislación de parejas de hecho y la eventual relación que pudiera tener con el derecho civil propio de las Comunidades Autónomas».

$\mathrm{El}$ argumento definitivo, utilizado por el TC, para justificar que la declaración de inconstitucionalidad del pár. 5. ${ }^{\circ}$ del artículo 174.3 LGSS es respetuosa con la competencia autonómica, prevista en el artículo 149.1.8..$^{\circ} \mathrm{CE}$, es el siguiente: «(...) atendiendo a su contenido, es claro que el precepto cuestionado no tiene por objeto la regulación de las parejas de hecho, ni guarda tampoco relación con las competencias autonómicas en materia de Derecho civil, porque no se trata de modificar, conservar o desarrollar el Derecho civil foral, lo que derivaría en diferencias consecuencia de coexistencia de distintos derechos civiles en el ordenamiento español. En realidad se trata de una norma de Segu-

${ }^{36}$ El Abogado del Estado, el Fiscal General del Estado y la Letrada de la Seguridad Social entendían que el pár. 5. ${ }^{\circ}$ del artículo 174.3 LGSS era respetuoso con la competencia autonómica, por lo que no debía declararse su inconstitucionalidad. 
ridad Social que, por referencia a otras normas, regula, exclusivamente la forma de acreditar los requisitos para el acceso a una prestación de la Seguridad Social, la pensión de viudedad en el caso de parejas de hecho estables. Esto es, la finalidad de la norma es concretar los requisitos para acreditar la existencia de una unión de hecho a efectos de reconocer al superviviente el derecho a percibir una pensión de viudedad. Por tanto, como el Auto del Tribunal Supremo apunta, el párrafo quinto del artículo 174.3 LGSS no constituye una norma de legislación civil vinculada al artículo 149.1.8 CE, sino una norma de Seguridad Social que, en principio y salvo justificación suficiente que no concurre en este caso, debería establecer los requisitos que las parejas de hecho tienen que cumplir para poder lucrar en su momento una pensión de viudedad con el más exquisito respeto al principio de igualdad» (FJ 5. ${ }^{\circ}$.

En suma, el TC entiende que la declaración de inconstitucionalidad de la norma jurídica, contenida en el pár. 5. ${ }^{\circ}$ del artículo 174.3 LGSS, respetaba la competencia autonómica sobre Derecho civil, atribuida a algunas CCAA ex artículo 149.1.8 CE, ya que se trataba de una norma de la Seguridad Social, cuya finalidad era la concreción de los requisitos de constitución y acreditación de las parejas de hecho a efectos de lucrar una pensión de viudedad. A sensu contrario, el precepto declarado inconstitucional y nulo - pár. $5 .^{\circ}-$ no era una norma civil, vinculada al artículo 149.1.8 CE, porque su función no era regular las parejas de hecho, ni guardaba tampoco relación con las competencias autonómicas en materia de Derecho civil relativas a la modificación, conservación o desarrollo del Derecho civil foral.

\section{LA INEXISTENCIA DE VÍNCULO MATRIMONIAL PREVIO EX ARTÍCULO 174.3 LGSS: SU CONSTITUCIONALIDAD POR LA STC 44/2014}

El pár. $4 .^{\circ}$ del artículo 174.3 LGSS condiciona la existencia de la pareja de hecho - a efectos de obtener la pensión de viudedad-, al cumplimiento de un presupuesto previo de carácter subjetivo relativo a que los miembros de la pareja de hecho no se hallen impedidos para contraer matrimonio y no tengan un vínculo matrimonial subsistente con otra persona. Este presupuesto también ha sido objeto de análisis en el seno del TC.

El supuesto de hecho debatido era el siguiente: una conviviente de hecho, separada por sentencia de 18 de abril de 1984 de un matrimonio anterior y no divorciada, ejercita una demanda ante al Juzgado de lo 
Social n. ${ }^{\circ} 2$ de León, tras la denegación por el INSS de la pensión de viudedad ante la falta del presupuesto de no tener vínculo matrimonial anterior. Dicho Juzgado, a la vista de los hechos formulados, dictó la sentencia de 31 de enero de 2010, desestimando la pretensión con el mismo argumento. Contra la anterior sentencia, la parte actora interpuso recurso de suplicación, esgrimiendo la vulneración de los artículos 14 y $139.1 \mathrm{CE}$, alegando que dado que el pár. 5. ${ }^{\circ}$ del artículo 174.3 LGSS hacía depender la «consideración» de la pareja de hecho de lo que se estableciese en la legislación específica en las CCAA con Derecho civil propio, se contemplaban para la pensión de viudedad requisitos de acceso y conservación diversos por razón de la vecindad civil. De este modo, mientras que en algunas CCAA (como en Castilla-León) se exigía la inexistencia de vínculo matrimonial vigente para constituir una pareja de hecho (motivo por el que se denegó a la actora la pensión, al no haberse divorciado), en otras (como Madrid, Cantabria y Canarias) se permitía su formalización a pesar de la existencia de tal vínculo.

La Sala de lo Social del TSJ de Castilla y León, sede de Valladolid, después de oír a las partes personadas y al MF, en virtud del Auto de 28 de septiembre de 2011 decide promover una cuestión de inconstitucionalidad, en relación con el artículo 174.3 párrafo $4 .^{\circ}$, en el inciso «no tengan vínculo matrimonial con otra persona» y párrafo $5 .^{\circ}$ de la LGSS. Las dudas de constitucionalidad que asaltan a dicha Sala en relación con el artículo 174.3 LGSS son dos. Por un lado, considera que podría entenderse contraria al derecho a la igualdad del artículo $14 \mathrm{CE}$, en el sentido expresado en el artículo 139.1 CE, la posibilidad conferida en el artículo 174.3 LGSS de que las CCAA dicten una regulación de las parejas de hecho que se separe de la regulación contenida en dicho artículo; de manera que los requisitos para el acceso a la prestación de viudedad sean distintos en función de la vecindad civil. Por otro, aprecia que el artículo 174.3 LGSS podría entenderse también contrario al derecho a la igualdad ante la ley en relación a la distinción que hace a efectos prestacionales entre parejas de hecho constituidas por uno o dos miembros con vínculo matrimonial vigente (sin derecho de pensión) y parejas de hecho en las que los dos miembros carecen de vínculo matrimonial vigente por haberse disuelto por divorcio (que sí tienen derecho a pensión). A juicio de la Sala, se estaría diferenciando sin causa razonable y proporcionada entre dos supuestos que, a otros efectos (a saber, en el caso de la pensión de viudedad a favor del cónyuge separado o divorciado) resulta irrelevante en la misma ley. Entiende que si puede causar pensión de viudedad el antiguo cónyuge del causante, sin diferenciarse entre separación y divorcio, pudiera no existir motivación razonable y suficiente para efec- 
tuar tal distinción en los casos de pensión de viudedad de las parejas de hecho; de modo que podría afectar a la constitucionalidad del inciso «no tengan vínculo matrimonial con otra persona» del artículo 174.3 LGSS.

Respecto de la primera duda de constitucionalidad, planteada por la Sala de lo Social del TSJ Castilla-León, en relación con el párr. 5. ${ }^{\circ}$ del artículo 174.3 LGSS, por la posible vulneración del principio de igualdad, el TC en el FD $2 .^{\circ}$ de la sentencia que se analiza de 7 de abril de 2014, remite a la STC de 11 de marzo de 2014 - examinada en el epígrafe anterior - . En esta última sentencia se declaraba la inconstitucionalidad y nulidad del pár. 5. ${ }^{\circ}$, por vulneración del artículo $14 \mathrm{CE}$ en relación con el artículo 149.1.17 CE, por lo que el TC desestima en este punto la presente cuestión de inconstitucionalidad por desaparición sobrevenida del objeto.

En cuanto a la segunda duda de constitucionalidad planteada sobre si la distinción, recogida en el pár. $4 .^{\circ}$ del artículo 174.3 LGSS, entre las parejas de hecho en la que alguno de sus miembros mantiene vínculo matrimonial vigente con otra persona - que no recibirían pensión de viudedad - y las parejas de hecho en las que los dos miembros carecen de vínculo matrimonial vigente por haberse disuelto por divorcio - que sí obtendrían pensión de viudedad - puede vulnerar el principio de igualdad, el TC en su FD 3. ${ }^{\circ}$ entiende que la Sala proponente de la cuestión de inconstitucionalidad no ofrece un término válido de comparación para efectuar el juicio de igualdad. En su opinión, no es que a unas parejas de hecho se les reconozca el derecho a la pensión de viudedad y a otras no, sino que determinadas uniones de hecho - aquellas en las que uno o ambos miembros están unidas por un vínculo matrimonial previo - no tienen la consideración de parejas de hecho a efectos prestacionales del artículo 174.3 LGSS $^{37}$, lo que constituye una opción libremente adoptada por el legislador a la hora de acotar el supuesto de hecho regulado que no resulta prima facie arbitraria o irracional. Por esta razón, argumenta el TC, el juicio comparativo no se postula con referencia a grupos o categorías de personas que encontrándose en una misma situación resulten irrazonablemente diferenciados por el legislador sino, por el contrario, respecto de dos posiciones jurídicas diversas

${ }^{37}$ El TC señala en su FD 3. ${ }^{\circ}$ que «el artículo 174.3 LGSS condiciona la existencia misma de la pareja de hecho, a los efectos de poder optar a obtener la pensión, al cumplimiento de un presupuesto previo de carácter subjetivo, consistente en que los sujetos no se hallen impedidos para contraer matrimonio y que no tengan un vínculo matrimonial subsistente con otra persona (...). Quiere ello decir que, a los efectos de la Ley no son parejas estables que queden amparadas por su regulación las que no reúnan esos precisos requisitos para su existencia». 
en las que, frente a la regulación legal, puede encontrarse un mismo individuo según haya decidido establecer una relación de hecho sin disolver previamente el vínculo matrimonial que tenía con otra persona o una vez que este vínculo haya quedado extinguido.

Por otro lado, el TC razona sobre la comparación — recogida en el Auto de planteamiento - entre el régimen jurídico de la pensión de viudedad de las parejas de hecho - art. 174.3 LGSS - y el de la pensión de viudedad del que sea o haya sido cónyuge en casos de «separación y divorcio» - art. 174.2 LGSS - . Llega a la conclusión de que las situaciones ofrecidas de contraste - unión matrimonial y unión de hecho- en el Auto proponente de la cuestión de inconstitucionalidad no resultan equiparables, pues como ha declarado reiteradamente el TC, el matrimonio es una institución social garantizada por nuestra norma suprema y el derecho a contraerlo es un derecho constitucional (art. 32.1 $\mathrm{CE}$ ), cuyo régimen jurídico corresponde a la ley por mandato constitucional (art. 32.2 CE); sin embargo, la unión de hecho more uxorio, ni es una institución jurídicamente garantizada ni hay un derecho constitucional expreso a su establecimiento. Por tanto, al existir evidentes diferencias entre ambas instituciones jurídicas, su equiparación conceptual no resulta posible (STC 93/2013, de 23 de abril), ni siquiera bajo la invocación del artículo 14 CE.

En suma, el TC entiende que el presupuesto de no tener vínculo matrimonial previo con otra persona, exigido a las parejas de hecho en el pár. 4. ${ }^{\circ}$ del artículo 174.3 LGSS, es plenamente constitucional y obedece al «objetivo legítimo de proporcionar seguridad jurídica en el reconocimiento de pensiones y de coordinar internamente el sistema prestacional de la Seguridad Social, evitando la concurrencia de títulos de reclamación que den lugar a un doble devengo de la pensión» $\left(\right.$ FD $\left.3 .^{\circ}\right)$. Con esta interpretación legal, realizada por el TC, se evita que una misma persona - conviviente de hecho con vínculo matrimonial previo con otra - puede obtener dos pensiones de viudedad distintas. Así, si el conviviente de hecho sigue manteniendo subsistente el vínculo matrimonial con otra persona, no podrá obtener la pensión de viudedad por la vía del artículo 174.3 párr. 4 . $^{\circ}$ LGSS, al exigir expresamente dicho precepto legal la inexistencia de un vínculo conyugal anterior con otra persona; no obstante, sí podría acceder a la pensión de viudedad por la vía del artículo 174.2 pár. 2. ${ }^{\circ}$ LGSS que reconoce el derecho a la pensión de viudedad, en los casos de separación o divorcio, a favor de quien sea o haya sido cónyuge legítimo «siempre que no hubiera contraído nuevas nupcias o hubiera constituido como pareja de hecho». 


\section{LA ACREDITACIÓN FORMAL DE LA PAREJA DE HECHO EX ARTÍCULO 174.3 LGSS: SU CONSTITUCIONALIDAD POR LAS SSTC 45/2014, 51/2014 Y 60/2014}

También se le ha preguntado al TC sobre la constitucionalidad de la exigencia de que la pareja de hecho deba constituirse de manera formal, mediante la correspondiente inscripción en el Registro de parejas de hecho o en documento público. La Sala de lo Social del TSJ de Castilla y León, sede en Valladolid, por Auto de 27 de septiembre y Auto de 26 de octubre de 2011 ha promovido dos cuestiones de inconstitucionalidad $-\mathrm{n} .{ }^{\circ} 6589-2011$ y n. $^{\circ} 6487-2011-$ respecto del párrafo 5..$^{\circ}$ en relación con el párrafo $4 .^{\circ}$ del artículo 174.3 LGSS, por posible vulneración de los artículos 14, 139.1 y 149.1.17 CE. En sentido similar, el Juzgado de lo Social n. ${ }^{\circ} 3$ de Talavera de la Reina por Auto de 22 de octubre de 2013 plantea también una cuestión de inconstitucionalidad - n. ${ }^{\circ} 7142-2013-$, apoyándose en similares argumentos jurídicos. En todos los casos el supuesto de hecho era similar: tras el fallecimiento de uno de los integrantes de la pareja de hecho, el otro solicita la pensión de viudedad, denegándosela por no haberse constituido formalmente como pareja de hecho - no consta la inscripción en registro oficial, ni su constitución en un documento público-, como exige preceptivamente el párr. $4 .^{\circ}$ del artículo 174.3 LGSS.

Las dos posibles vulneraciones del principio de igualdad son las siguientes. Por un lado, los requisitos de acceso a la pensión de viudedad por parte de los convivientes de hecho son distintos en función del lugar donde residan (párrafos $4 .^{\circ}$ y $5 .^{\circ}$ del art. 174.3 LGSS); de modo que si los recurrentes, en vez de vivir en la Comunidad Autónoma de Castilla y León o de Castilla-La Mancha, hubieran residido en la Comunidad Autónoma de Cataluña - con competencia en materia de Derecho civil - , habrían accedido a la pensión de viudedad, al no exigirse el requisito de la constitución formal de la pareja de hecho. Por otro, que la regulación del párr. 4. ${ }^{\circ}$ del artículo 174.3 LGSS establece una diferencia de trato sin causa razonable y proporcionada entre las parejas de hecho inscritas y las no inscritas, pudiendo resultar exorbitante la exigencia del requisito de la inscripción en el Registro de parejas.

Respecto de la primera duda de constitucionalidad del párrafo $5 .^{\circ}$ en relación con el $4 .^{\circ}$ del artículo 174.3 LGSS, el TC en las sentencias citadas 45/2014, 51/2014 y 60/2014, que resuelven dichas cuestiones de inconstitucionalidad, remite a lo señalado en la STC 40/2014, de 11 de marzo, citada ampliamente en este trabajo. En esta última sentencia se declaraba la inconstitucionalidad y nulidad del pár. $5 .^{\circ}$, por lo que el 
TC acuerda la extinción de dichas cuestiones de inconstitucionalidad por desaparición sobrevenida de su objeto. En cuanto a la segunda duda de constitucionalidad relativa a la posible vulneración del principio de igualdad la exigencia de establecer una diferencia de trato entre las parejas de hecho inscritas y las no inscritas - prevista en el pár. $4 .^{\circ}$ del art. 174.3 LGSS - el TC ha señalado en las aludidas sentencias -45/2014, 51/2014 y 60/2014 - que dicho párrafo no vulnera el principio de igualdad ante la ley.

Conviene matizar que la Sala de lo Social del TSJ de Castilla y León invoca la doctrina sentada en la STC 199/2004, de 15 de noviembre, en la que se concede el amparo a la parte recurrente por infracción del artículo 14 CE ya que se le había denegado una pensión de viudedad por falta de inscripción de un matrimonio religioso en el Registro Civil. Sin embargo, para las SSTC 45/2014 y 60/2014 la doctrina sentada por la citada STC 199/2004 ${ }^{38}$ no resulta trasladable al caso enjuiciado en el proceso a quo, en el que la pensión de viudedad ha sido denegada al supérstite de una pareja de hecho no inscrita en el Registro administrativo correspondiente - con la antelación mínima exigida a la fecha del fallecimiento del causante de la pensión- y no a un matrimonio no inscrito en el Registro Civil, como ocurría en el supuesto resuelto por dicha STC. En su opinión, la aplicación al caso de dicha doctrina supondría identificar dos realidades jurídicas - matrimonio y convivencia extramatrimonial - que no resultan equivalentes y que están sometidas a un diverso régimen jurídico en materia de pensión de viudedad. Téngase en cuenta que conforme a la doctrina de la STC 93/2013, de 23 de abril, tal diversidad de tratamiento legal no resulta incompatible con el principio de igualdad, en tanto en cuanto solo el matrimonio es una institución social garantizada por la CE y el derecho a contraerlo es un derecho constitucional ex artículo 32.1 CE; circunstancias que no son predicables de la unión de hecho more uxorio.

El TC entiende en esta materia que el trato desigual por sí mismo considerado no es necesariamente contrario a la CE, pues no toda desigualdad de trato legislativo en la regulación de una materia entraña una vulneración del derecho fundamental a la igualdad ante la ley del artículo $14 \mathrm{CE}$, sino únicamente aquellas que introduzcan una diferencia de trato entre situaciones que puedan considerarse sustancialmente

38 En la STC 199/2004, de 15 de noviembre, se había concedido el amparo solicitado a la parte recurrente por infracción del artículo 14 CE ya que se le había denegado una pensión de viudedad por falta de inscripción de un matrimonio canónico en el Registro Civil. 
iguales y sin que posean una justificación objetiva y razonable ${ }^{39}$. En concreto, la STC 45/2014 señala en el FJ 3. ${ }^{040}$ : «(...) si atendemos a la regulación del artículo 174.3 LGSS, constatamos que no es que a unas parejas de hecho se le reconozca el derecho a la prestación y a otras no, sino que, a los efectos de la Ley, unas no tienen la consideración de pareja de hecho y otras sí. (...) Quiere ello decir que, a los efectos de la Ley, no son parejas estables que queden amparadas por su regulación las que no reúnan todos esos precisos requisitos, lo que supone una opción adoptada por el legislador a la hora de acotar el supuesto de hecho regulado que no resulta prima facie arbitraria o irracional. En efecto, desde ese enfoque, al igual que reconocimos en la STC 93/2013, de 23 de abril, FJ 7, que el legislador puede establecer regímenes de convivencia more uxorio con un reconocimiento jurídico diferenciado al del matrimonio, estableciendo ciertas condiciones para su efectivo reconocimiento y atribuyéndole determinadas consecuencias, cabe razonar ahora que el reconocimiento de esas realidades familiares no impone al legislador otorgar un idéntico tratamiento a la convivencia more uxorio acreditada y a la no acreditada, o a la que se verifique por medio de los mecanismos probatorios legalmente contemplados frente a la que carece de ellos, pues no es irrazonable definir a aquellos como los que garantizan que la atribución de derechos asociada cumplirá las exigencias de la seguridad jurídica».

En consecuencia, el TC consolida la doctrina jurisprudencial de que la exigencia de la constitución formal - ad solemnitatem - de la pareja de hecho con una antelación mínima a la fecha del fallecimiento del causante, tal como exige el párrafo $4 .^{\circ}$ del artículo 174.3 LGSS, no vulnera el derecho a la igualdad, al no resultar un presupuesto «exorbitante», ya que su finalidad es la constatación de la convivencia entre los miembros de una pareja de hecho y la identificación de la existencia de una concreta situación de necesidad merecedora de la protección a través de la pensión de viudedad del sistema de la Seguridad Social ${ }^{41}$.

39 Vid., la STC 131/2013, de 5 de junio, en su FJ 5.․

${ }^{40}$ Dicha fundamentación jurídica se repite en los mismos términos en el FJ $3 .^{\circ}$ de la STC 60/2014, de 5 de mayo.

${ }^{41}$ Por su parte, los magistrados doña Encarnación Roca Trías y don Juan Antonio Xiol Ríos en el Voto particular que formulan a la STC de 5 de mayo de 2014 se muestran contrarios a la afirmación que se hace en la Sentencia de que el precepto cuestionado no establece una diferencia de trato entre parejas de hecho inscritas o constituidas en documento público y las que no, y que se fundamenta en que, a los efectos del artículo 174.3.4. ${ }^{\circ}$ LGSS, las primeras sí tienen la consideración de pareja de hecho, mientras que las restantes no. En opinión de dichos magistrados: «Podrá negarse la pensión 
De este modo, únicamente las parejas de hecho inscritas o constituidas en documento público tienen la consideración de pareja de hecho a efectos de conseguir una pensión de viudedad. Las restantes uniones de hecho no acreditadas - ni inscritas en Registro de parejas de hecho ni en documento público - no podrán acceder a una pensión de viudedad, con independencia de que se les puedan reconocer plenos efectos jurídicos en el ámbito del Derecho civil. En este sentido y sin ánimo de ser exhaustivos, $c f r$., la actual regulación de las parejas de hecho, contenida en la Ley 25/2010, de 29 de julio, del libro segundo del Código civil de Cataluña, relativo a la persona y a la familia, donde el artículo 234.1 establece que dos personas que conviven en una comunidad de vida análoga a la matrimonial se considerará pareja estable en cualquiera de los siguientes casos: a) si la convivencia dura más de dos años ininterrumpidos; b) si durante la convivencia, tienen un hijo en común; c) si formalizan la relación en escritura pública. En virtud de su reconocimiento como pareja de hecho, se establecen toda una serie de previsiones en relación con el régimen económico mientras dura la convivencia (art. 234.3), con los efectos por su extinción voluntaria (arts. 234.7 a 234.11) o por causa de muerte, en que el superviviente tiene incluso los derechos viudales familiares de los artículos 231.30 y 231.31 (art. 234.10). Como puede

de viudedad a las parejas estables que conforme al Derecho civil propio catalán tienen esa consideración por mantener una convivencia de dos años ininterrumpidos o por haber tenido un hijo común durante la convivencia; pero, no podrá negarse que son parejas de hecho conforme al único Derecho civil que les es de aplicación» (razón 2. ${ }^{a}$ ).

Además, inciden en la razón 4. a que «el razonamiento utilizado en la Sentencia hubiera resultado asumible en sus consecuencias en un contexto normativo como el diseñado originariamente por la Ley 40/2007, de 4 de diciembre, que respondía a la existencia de territorios con Derecho civil propio que en el legítimo ejercicio de sus competencias podían regular las parejas de hecho sin que se les impusiera la existencia de registros públicos para su inscripción o su constitución en documento público. Sin embargo, la nulidad del artículo 174.3, párrafo quinto, LGSS acordada por la STC 40/2014 vino a modificar ese marco normativo, de tal modo que la actual limitación de los supuestos de acreditación de la existencia de pareja de hecho a los que estén inscritas en un registro o constituidas en un documento público, excluyendo cualquier otro medio de prueba admitido en derecho o su acreditación de conformidad con lo establecido en la normativa de Derecho civil propio que resulte de aplicación, resulta desproporcionado». Por este motivo, entienden que «esta desproporción, en suma, es la que, a nuestro juicio, hubiera debido llevar a declarar la inconstitucionalidad del precepto cuestionado, pues el desconocimiento del principio de diversidad de los derechos civiles propios, en que incurre, según entendemos, la STC 40/2014, contra la que en su momento formulamos Voto particular, en combinación con la doctrina seguida por la Sentencia mayoritaria, origina una discriminación». 
observarse, el Derecho civil catatán otorga eficacia jurídico-civil a parejas de hecho no inscritas o constituidas en documento público.

\section{A MODO DE CONCLUSIÓN}

La atribución de la pensión de viudedad a las parejas de hecho ha sido una materia no exenta de polémica jurisprudencial, sobre todo en lo relativo a la posible vulneración del principio de igualdad del artículo 14 CE. En un primer momento se planteó la duda de si el no reconocimiento legal de dicha prestación a las uniones de hecho, podía conculcar el principio de igualdad. El TC entendió que no se generaba discriminación alguna entre personas casadas y en pareja, el hecho de que las primeras tuvieran reconocida dicha pensión y las segundas no. Para justificar su posición jurídica, creó la conocida doctrina jurisprudencial (STC 184/1990, de 15 de noviembre) que está aún en vigor: «el matrimonio y la convivencia extramatrimonial no son realidades equivalentes. El matrimonio es una institución social garantizada por la Constitución, y el derecho del hombre y de la mujer a contraerlo es un derecho constitucional (art. 32.1). (...) Nada de ello ocurre con la unión de hecho more uxorio, que ni es una institución jurídicamente garantizada ni hay un derecho constitucional expreso a su establecimiento».

El paso del tiempo unido a la importancia que han adquirido las nuevas formas de familia ha llevado a que el legislador de la Seguridad Social reconozca la pensión de viudedad a las parejas hecho en la Ley 40/2007 MMSS; ahora bien, con presupuestos de acceso distintos a los exigidos a las personas casadas. Esto ha generado que nuevamente se hayan planteado dudas constitucionales, en lo concerniente a si el cumplimiento de determinados presupuestos podía lesionar el derecho a la igualdad de unas parejas de hecho frente a otras ya que, como se ha venido señalando a lo largo de este trabajo, no se ha reconocido la pensión de viudedad a todas las uniones de hecho sino a aquellas que se encuentran en una situación de desequilibrio económico o estado de necesidad y cumplan unos determinados requisitos formales y de convivencia ex artículo 174.3.4. . LGSS.

Lo más significativo es que el TC ha declarado la inconstitucionalidad - y la consiguiente derogación - del párr. 5. ${ }^{\circ}$ del artículo 174.3 LGSS, por conculcar el principio de igualdad (STC 40/2014, de 11 de marzo). Dicha derogación ha resultado trascendental porque a partir de ahora los presupuestos, que deben concurrir para lucrar la pensión de viudedad, serán los mismos - párr. 4. ${ }^{\circ}$ del art. 174.3 LGSS - para to- 
dos los convivientes de hecho con independencia de su residencia civil ${ }^{42} ; \mathrm{y}$, sobre todo, porque ha puesto fin a la técnica de remitir a las correspondientes leyes autonómicas de parejas de hecho de las CCAA con competencia en materia de Derecho civil $^{43}$, que generaba una desigualdad de trato entre los convivientes de hecho en función del lugar de su residencia ${ }^{44}$.

Respecto del acceso a la pensión de viudedad por parte de las parejas de hecho homosexuales, el TC no ha mantenido un criterio uniforme. En la sentencia 41/2013, de 14 de febrero, ha considerado inconstitucional el presupuesto de «haber tenido hijos en común» de la DA $3 .{ }^{\mathrm{a}}$ de la Ley 40/2007, al entender que dicho requisito era de imposible cumplimiento por parte de las uniones homosexuales, a las que no se les permitió la adopción durante bastante tiempo. Y, sin embargo, en la sentencia 92/2014, de 10 de junio, se muestra partidario de la constitucionalidad del artículo 174.1 LGSS - en la redacción dada por el art. 32.1 de la Ley 50/1998, de 30 de diciembre-, que excluía a las parejas de hecho homosexuales de la pensión de viudedad, al no estarles permitido contraer matrimonio hasta la Ley 13/2005.

${ }^{42}$ En el ámbito civil Bercovitz, R., («La pensión de viudedad y las parejas de hecho», Revista Doctrinal Civil-Mercantil, n. ${ }^{\circ}$ 9, 2015, p. 3) se pronuncia partidario de dar un marco legislativo unitario a las parejas de hecho more uxorio. En su opinión, «(...) las parejas de hecho constituyen un sucedáneo del matrimonio. Y de la misma manera que la regulación del matrimonio debe ser unitaria, y así está constitucionalmente reconocido (art. 32 CE) (...), por la misma razón, aunque no esté constitucionalmente reconocido, sería preferible que quien se empareja more uxorio en Galicia se acogiese también al mismo régimen y con los mismos requisitos que quien lo hace en Andalucía, o en Cataluña, o en Valencia o en Extremadura».

${ }^{43}$ Para Rubio ToRRAno («La diferente regulación de la pensión de viudedad en las parejas de hecho y el principio constitucional de igualdad», Revista Doctrinal Civil-Mercantil, n. ${ }^{\circ} 3,2014$, p. 3): «(...) la desatención por parte del legislador estatal de las parejas de hecho y, en cambio, la actividad desenfrenada por parte de las Comunidades autónomas, han creado, y lo van a seguir haciendo, numerosos problemas de difícil solución, poniendo en un brete al Tribunal Constitucional que tiene que hacer verdaderos juegos malabares para poner cierto orden en esta materia (léase, rectificando cuando se hace preciso su propia doctrina) para evitar mayores desaguisados».

${ }^{44}$ A favor de la derogación de la técnica de la remisión a las normas jurídico-civiles - art. 97 CC - en los supuestos de pensión de viudedad de separados y divorciados ante los problemas de desprotección y sobreprotección detectados, ya me he pronunciado en otros trabajos. Vid., UREÑa MARTíneZ, M., «La pensión compensatoria tras la reforma de la pensión de viudedad», en Mujeres, contratos y empresa desde la igualdad de género, dir., Mesa Marrero, C., Tirant lo Blanch, Valencia, 2014, pp. 992 y ss.; y «Crisis matrimoniales y pensión de viudedad (Especial consideración al presupuesto de la pensión compensatoria)», Cuadernos de Aranzadi Civil, n. ${ }^{\circ}$ 47, Aranzadi, 2011,pp. 97 y ss. 
En otras ocasiones que se le ha preguntado, el TC se ha pronunciado partidario de la constitucionalidad de determinados presupuestos exigidos, para la obtención de la pensión de viudedad: no tener vínculo matrimonial previo con otra persona (STC 44/2014, de 7 de abril) o que la pareja de hecho deba constituirse de manera formal mediante la correspondiente inscripción en el Registro de parejas de hecho o en documento público (SSTC 45/2014, de 7 de abril y 60/2014, de 5 de mayo). En estos casos ha legitimado plenamente al legislador de la Seguridad Social, entendiendo que no se aprecia una vulneración del principio de igualdad, el hecho de que determinadas parejas, que se inscribieron en algún Registro de parejas de hecho o formalizaron su unión en un documento público, puedan acceder a la pensión de viudedad frente a otras que no lo hicieron.

Pese a que las diferencias de trato aludidas - matrimonio versus parejas de hecho - en torno a la pensión de viudedad no son consideradas por la doctrina constitucional contrarias al principio de igualdad, sería conveniente que el legislador de la Seguridad Social repensara la pensión de viudedad con carácter integral y la configurara con una misma fundamentación material ${ }^{45}$, con independencia de que el favorecido por dicha prestación sea una persona casada o se encontrara en pareja de hecho. Probablemente en el momento actual ya no tenga sentido dispensar una protección jurídica mayor a las personas casadas respecto de las que no lo están, por más que el TC se empeñe en recordar que dichas instituciones jurídicas no son realidades equivalentes y está jus-

45 Mella Méndez [ «El concepto de "pareja de hecho" a efectos de la pensión de viudedad», Revista doctrinal Aranzadi social, n. ${ }^{\circ}$ 9, 2012, p. 20 (BIB 2017, 17)] critica la exigencia del desequilibrio económico o necesidad económica que se exige al supérstite de la pareja de hecho para la atribución de la pensión de viudedad. La crítica se basa en el desigual tratamiento con el sobreviviente de la pareja matrimonial, para el que el citado desequilibrio se presume y tiene que probarse. Para la autora, «la solución no debe ser la de eliminar esa exigencia para la pareja de hecho, sino el extenderla para la matrimonial. La necesaria y pendiente reforma integral de la pensión de viudedad quizá deba ligar, inexorablemente, el derecho a la misma a las situaciones de necesidad reales, máxime en tiempo de crisis y por analogía con lo que sucede en el resto de prestaciones del sistema público de Seguridad Social».

En parecidos términos se expresan BlázQuez Agudo, E. M. a y Presa GarCÍA-LóPEZ, R., («Pensión de viudedad para las parejas de hecho: evolución normativa y jurisprudencial», op . cit., p. 180): «Si la evolución de la pensión es hacia la asistencialidad, sería deseable que se demandase a todos la prueba de la falta de rentas al fallecimiento del causante, lo que llevaría a justificar este beneficio desde la lógica del apoyo familiar en el supuesto de fallecimiento de uno de sus miembros sustentadores con el fin de apoyar la continuidad económica del núcleo familiar». 
tificado su tratamiento jurídico desigual. Entiendo que la mejor opción sería conceder un tratamiento legal equivalente al matrimonio y a las parejas de hecho ${ }^{46}$, porque la pensión de viudedad es una prestación fundamentada en la protección a la familia y el artículo 39.1 CE ordena a los poderes públicos que garanticen la protección social, económica y jurídica de la misma, sin realizar ninguna distinción en atención a una determinada modalidad familiar ${ }^{47}$.

\section{BIBLIOGRAFÍA}

Alarcón Castellano, M. M. y Roldán Martínez, A.: «Algunas reflexiones críticas sobre la pensión de viudedad de las parejas de hecho», Revista de Trabajo y Seguridad Social, n. ${ }^{\circ}$ 319, 2009.

Apilluelo Martín, M.: «La pensión de viudedad tras la nueva Ley 40/2007, de 4 de diciembre, de medidas en materia de Seguridad Social», Actualidad Laboral, n. . 9, 2008.

BERCOVITZ, R.: «La pensión de viudedad y las parejas de hecho», Revista Doctrinal Civil-Mercantil, n. ${ }^{\circ}$ 9, 2015.

Blasco Jover, C.: «La igualdad ante la exigencia de pensión compensatoria para lucrar viudedad en parejas de hecho», en NREDT, 168, 2014, p. 210.

BlázQuez Agudo, E. M. a y PRESA García-LóPEZ: «Pensión de viudedad para las parejas de hecho: evolución normativa y jurisprudencial», $N R D T, 168$, 2014.

Desdentado Daroca, E.: La pensión de viudedad ante los nuevos retos del Derecho de Familia: Un estudio para una prestación en crisis, Bomarzo, Albacete, 2009.

${ }^{46}$ En una dirección similar se expresan Moreno VidA, M. a N., y Monereo Pérez, J. L., «Epílogo. Hacia un nuevo modelo de regulación de la pensión de viudedad», en La pensión de viudedad. Una necesaria reforma ante los cambios en las estructuras familiares, dir., Moreno Vida, M. ${ }^{a}$ N., Monereo Pérez, J.L., y Díaz Aznarte, M. a T., Comares, Granada, 2013, p. 319.

${ }^{47}$ Como señala Molina Navarrete, C., («La multiculturalidad, el pluralismo de relaciones de convivencia en pareja y el derecho social: entre tradición y renovación», en Derecho Privado y Constitución, n. ${ }^{\circ} 21$, Madrid, 2007, p. 310) «debe garantizarse una auténtica neutralidad del régimen jurídico predispuesto para la organización de la vida en pareja, por tanto del modelo familiar elegido en general, de modo que realmente obedezca a un ejercicio libre y no condicionado por las mayores o menores ventajas fiscales, laborales y sociales de una opción u otra. Es la familia lo que debe contar con apoyo, precisamente para que también las "cargas familiares" no resulten un impedimento ni a la libertad de elección ni a la igualdad de oportunidades (...) El pluralismo social debe conllevar un tratamiento equivalente. No es la forma matrimonial o no, sino la concreta situación relacional creada, la que debe determinar la acción jurídica». 
Desdentado Daroca, E.: La pensión de viudedad. Retos del Derecho de Familia y reflexiones sobre las últimas reformas, Bomarzo, Albacete, 2013.

DíAZ AzNARTE, M. T.: «Las prestaciones por muerte y supervivencia en el ordenamiento jurídico español tras la Ley 40/2007, de 4 de diciembre, de medidas en materia de la Seguridad Social», en Monereo PÉrez, J. L. (dir.), La reforma de la Seguridad Social. Estudio sistemático de la Ley 40/2007, de 4 de diciembre, de medidas en materia de Seguridad Social, La Ley, Madrid, 2008.

Gutiérrez-Solar Calvo, B.: «Pensión de viudedad y convivencia extramatrimonial: un motivo más para una necesaria reforma del artículo 174 LGSS», Relaciones Laborales, n. ${ }^{\circ}$ 7, 2005.

LAmARCA, A. y Alascio, L.: «Parejas de hecho y pensión de viudedad», en Indret, 2007, n. $^{\circ} 4$.

MARTÍNEZ ABASCAL: «Las parejas de hecho y la pensión de viudedad en la Ley 40/2007, de 4 de diciembre: ¿una equiparación inviable?», Revista doctrinal Aranzadi Social, n. ${ }^{\circ}$ 17, 2010.

MELla MÉNDEZ: «El concepto de "pareja de hecho" a efectos de la pensión de viudedad», Revista doctrinal Aranzadi Social, n. ${ }^{\circ}$ 9, 2012 (BIB 2012, 17).

Molina NAVARRETE, C.: «La multiculturalidad, el pluralismo de relaciones de convivencia en pareja y el derecho social: entre tradición y renovación», en Derecho Privado y Constitución, n. . 21, Madrid, 2007.

Molins GarcíA-AtAnCE, J.: «La pensión de viudedad en la Ley 40/2007, de medidas en materia de Seguridad Social», Revista doctrinal Aranzadi Social, n. ${ }^{\circ}$ 6, 2008 (BIB 2008, 1180).

Moreno Gené, J.: «"Pensión especial de viudedad”» para parejas de hecho sin hijos comunes, Revista doctrinal Aranzadi Social, n. ${ }^{\circ}$ 2, 2013 (BIB 2013, 944).

Moreno Vida, M. ${ }^{a}$ N. y Monereo Pérez, J. L.: «Epílogo. Hacia un nuevo modelo de regulación de la pensión de viudedad», en La pensión de viudedad. Una necesaria reforma ante los cambios en las estructuras familiares, dir., Moreno Vida, M. ${ }^{a}$ N., Monereo Pérez, J.L. y Díaz Aznarte, M. ${ }^{\text {a }}$ T., Comares, Granada, 2013.

PANIZO RoBles, J. A.: «La convivencia de hecho y su incidencia en las prestaciones de la Seguridad Social: una deuda de cobertura pendiente», Justicia Laboral, 2005, n. $^{\circ} 24$.

Pérez Alonso, M. A.: Nueva pensión de viudedad y orfandad en el Régimen General de la Seguridad Social, Tirant lo Blanch, Valencia, 2008.

PoQuet CATAlÁ, R.: «El acceso de las parejas de hecho a la pensión de viudedad: ¿una realidad?, Temas Laborales, n. ${ }^{\circ}$ 119, 2013.

RoDRÍGUEZ INIESTA, G.: «La protección por muerte y supervivencia», en CAVAS MARTínEz, F. (dir.), La reforma de la seguridad social de 2007, Ediciones Laborum, Murcia, 2007. 
Rubio TORRANO: «La diferente regulación de la pensión de viudedad en las parejas de hecho y el principio constitucional de igualdad», Revista Doctrinal Civil-Mercantil, n. ${ }^{\circ}$ 3, 2014.

SAMPEDro Corral, M.: «Modificaciones introducidas por la Ley 40/2007, de 4 de diciembre, en la prestación de muerte y supervivencia», Revista de Trabajo y Seguridad Social. CEF, n. ${ }^{\circ}$ 298, 2008.

TosCANi GiMÉnEZ, D.: «La reformulación de la pensión de viudedad en la Ley 40/2007: algunas reflexiones críticas», Revista de Trabajo y Seguridad Social. CEF, n. ${ }^{\circ}$ 302, 2008.

UREÑa MartíneZ, M.: «La pensión compensatoria tras la reforma de la pensión de viudedad», en Mujeres, contratos y empresa desde la igualdad de género, dir., Mesa MARrero, C., Tirant lo Blanch, Valencia, 2014.

- «Crisis matrimoniales y pensión de viudedad (Especial consideración al presupuesto de la pensión compensatoria)», Cuadernos de Aranzadi Civil, n. ${ }^{\circ}$ 47, Aranzadi, 2011. 